IZA DP No. 7980

The Effect of Labor Migration on the

Diffusion of Democracy:

Evidence from a Former Soviet Republic

Toman Omar Mahmoud

Hillel Rapoport

Andreas Steinmayr

Christoph Trebesch

February 2014 


\title{
The Effect of Labor Migration on the Diffusion of Democracy: Evidence from a Former Soviet Republic
}

\author{
Toman Omar Mahmoud \\ Kiel Institute for the World Economy \\ Hillel Rapoport \\ PSE - Université Paris 1 Panthéon-Sorbonne, \\ Bar-Ilan University and IZA \\ Andreas Steinmayr \\ University of St.Gallen \\ and University of Chicago \\ Christoph Trebesch \\ University of Munich \\ and CESifo
}

\section{Discussion Paper No. 7980 \\ February 2014}

\author{
IZA \\ P.O. Box 7240 \\ 53072 Bonn \\ Germany \\ Phone: +49-228-3894-0 \\ Fax: +49-228-3894-180 \\ E-mail: iza@iza.org
}

\begin{abstract}
Any opinions expressed here are those of the author(s) and not those of IZA. Research published in this series may include views on policy, but the institute itself takes no institutional policy positions. The IZA research network is committed to the IZA Guiding Principles of Research Integrity.

The Institute for the Study of Labor (IZA) in Bonn is a local and virtual international research center and a place of communication between science, politics and business. IZA is an independent nonprofit organization supported by Deutsche Post Foundation. The center is associated with the University of Bonn and offers a stimulating research environment through its international network, workshops and conferences, data service, project support, research visits and doctoral program. IZA engages in (i) original and internationally competitive research in all fields of labor economics, (ii) development of policy concepts, and (iii) dissemination of research results and concepts to the interested public.
\end{abstract}

IZA Discussion Papers often represent preliminary work and are circulated to encourage discussion. Citation of such a paper should account for its provisional character. A revised version may be available directly from the author. 


\section{ABSTRACT}

\section{The Effect of Labor Migration on the Diffusion of Democracy: Evidence from a Former Soviet Republic}

Migration contributes to the circulation of goods, knowledge, and ideas. Using community and individual-level data from Moldova, we show that the emigration wave that started in the late 1990s strongly affected electoral outcomes and political preferences in Moldova during the following decade and was eventually instrumental in bringing down the last ruling Communist government in Europe. Our results are suggestive of information transmission and cultural diffusion channels. Identification relies on the quasi-experimental context studied and on the differential effects arising from the fact that emigration was directed both to more democratic Western Europe and to less democratic Russia.

JEL Classification: F22, D72, O1

Keywords: emigration, political institutions, elections, social networks, information transmission, cultural diffusion

Corresponding author:

Toman Omar Mahmoud

Kiel Institute for the World Economy

Hindenburgufer 66

24105 Kiel

Germany

E-mail: toman.mahmoud@ifw-kiel.de

\footnotetext{
* We thank Esther Ademmer, Alberto Alesina, Irina Baraliuc, Ruxanda Berlinschi, Romeo Bernardo, Simone Bertoli, Bruno Biais, Christine Binzel, George Borjas, Igor Botan, Michael Clemens, Randolf David, Eva Deuchert, Oliver Falk, Jeff Grogger, Edilberto de Jesus, Asim Khwaja, Michael Lechner, David McKenzie, Alice Mesnard, Arash Nekoei, Nathan Nunn, Ben Olken, Lant Pritchett, Elena Prohnitchi, Valeriu Prohnitchi, Imran Rasul, Stefan Rother, Matti Sarvimäki, Carl von Schweinitz, Jesse Shapiro, Uwe Sunde, Erwin Tiongson, Bogdan Voicu, David Yanagizawa-Drott, Ekaterina Zhuravskaya, Clara Zverina as well as seminar/conference participants in Berlin, Bern, Chicago, Columbia, Geneva, Harvard, Hebrew University, Heidelberg, Kiel, Malaga, Manila, Moscow, Munich, St. Gallen, UCL, City University London, Vienna, and NEUDC 2013 for helpful comments and discussions. We are also very grateful to Iaroslav Baclajanschi, Vasile Cantarji, lurie Ciocan, Martin Raiser and Alexandr Socolov for their invaluable support in collecting the data for this project. All remaining errors are ours. We benefited from the paper development award from the Graduate Institute's Programme for the Study of Global Migration during the oikos Young Scholars Economics Academy 2012.
} 


\section{Introduction}

In a recent essay on the role of ideas and preferences as determinants of political change, Dani Rodrik (2014) noted that "Perhaps the single most important source of ideas and policy innovation are practices that prevail elsewhere." He used the concept of "emulation" to qualify the diffusion process of political ideas but did not elaborate on the channels through which they disseminate. One candidate channel for such diffusion is people. When people cross borders, they bring with them new goods, new knowledge, and new ideas. Agriculture, the alphabet, and virtually all great inventions, including institutions, diffused through human migration. ${ }^{1}$ Prior to World War II, people who migrated had only limited options for interacting with their homelands unless they chose to return. $^{2}$ In this context, Hirschman's (1970) exit, voice, and loyalty framework appears as a reasonable simplification to describe the menu of mutually exclusive political options that individuals have faced for the most part of modern history. In Hirschman's view, exit and voice are substitute ways for expressing political discontent, with more exit implying less voice. Hirschman illustrated his theory using the example of East Germany. His conclusion was that the emigration waves of the 1950s and 1960s had weakened the reformist voices, eventually strengthening the repressive communist regime (see also Hirschman, 1993; Pfaff and Kim, 2003). ${ }^{3}$ Recent literature, however, suggests that knowledge and ideas also circulate in the direction opposite to the direction of migration, that is, from destination to origin countries. While this has probably always been the case, it is only recently, with the globalization of the world economy and the availability of cheap communication and transport, that migration-driven reverse flows of knowledge and ideas have become sizeable.

\footnotetext{
1 Skoglund et al. (2012) study farmer migration and the diffusion of domesticated crops and animals in the neolithic age. Nunn and Qian (2011) and Hersh and Voth (2011) analyze the effects of the new goods imported from the Americas to Europe on a range of economic and demographic outcomes. Acemoglu et al. (2001) emphasize the role of colonial settlers and institutions to explain comparative development, while Acemoglu et al. (2011) study the institutional spillovers of the French occupation of parts of Western Europe after 1789. Hornung (2014) studies the human capital externalities from Huguenot immigration to Prussia, while Waldinger (2010, 2012) and Borjas and Doran (2012) study the emigration of scientists to the US, focusing on Nazi Germany in the 1930s and on Russia in the early 1990s, respectively.

2 Bandiera et al. (2013) show that return rates of European immigrants may have been much higher than previously thought - as high as fifty percent - for those who migrated to the United States in the early $20^{\text {th }}$ century.

${ }^{3}$ Similar analyses have been proposed with regard to autocratic regimes such as Cuba or Belarus, or for countries such as Haiti and Mexico, where it seems emigration largely served as a safety valve, relaxing domestic pressure to reform and, thus, delaying social and political change. See for example Hansen (1988) on Mexico, Colomer (2000) and Hoffman (2005) on Cuba, and Ferguson (2003) on Haiti.
} 
This paper investigates the effect of labor migration on political outcomes at home, using data from the former Soviet Republic of Moldova, an ideal context from our perspective, as we explain in detail in Section 2. It builds on the idea that while abroad migrants absorb new information and are exposed to new political attitudes, preferences, and practices that can spill over to their home communities through direct and indirect contacts with relatives, friends and other members of their home-based social networks. Ultimately, these immaterial cross-border flows have the potential to change political preferences and strengthen the constituency for political change and reform at home, especially in regions where information acquisition is difficult or costly, as is the case of many developing and transition countries.

Our objective is to empirically identify these spillover effects of labor migration on electoral and political preferences of those who stay behind. In particular, we test whether Moldovan municipalities that send migrants to democratic countries experience an increase in political support for more democratic and liberal parties in elections. Moldova became independent in 1991 and experienced a chaotic democratic transition during the first decade after independence, culminating in the return of the Communist Party to power in 2001. In 1998, the Russian financial crisis strongly affected Moldova's economy and sparked what would eventually become one of the largest recent emigration waves (in relative terms), with Moldovans emigrating first modestly and then massively to both Western Europe and Russia. It was only in 2009 that a coalition of pro-democracy and proEuropean parties took over, eventually leading to a rapid improvement in civil liberties and press freedom, and to the initiation of economic and political reforms.

This paper posits that exposure to Western political values and practices through emigration to Western European countries played an instrumental role in bringing about political change in Moldova. Our identification strategy relies on the quasi-experimental setting under which the episode of emigration we analyze took place. There was hardly any emigration out of Moldova before the Russian financial crisis of 1998. The crisis drastically affected Moldova's export markets and main sources of income, sparking the first waves of emigration. In just a few years, more than 300,000 Moldovans left the country. About $40 \%$ of them left for the liberal democracies of Western Europe and 60\% left for less democratic countries in the East, overwhelmingly Russia (Luecke et al., 2007). We exploit this bipolar pattern in terms of destination (West vs. East) and the large variation in political ideologies and democratic traditions across destination countries to test for destinationspecific spillover effects of emigration on electoral outcomes in the subsequent periods. 
For identification, we first document that the direction of migration flows varies greatly across observationally similar communities. No systematic spatial pattern exists once we control for observable community characteristics, in particular for factors driving the destination choice of the first migrants who departed at the end of the 1990s. We interpret the lack of a spatial pattern as indication that, conditional on observables, there is a considerable quasi-random component in the direction of early migration flows which set the path for subsequent migration flows during the 2000s. Our main challenge is that migrants' destination choices could have been driven by political preferences, or by a confounder that drives both migration and voting patterns. Political selfselection at the individual level (Hirschman's "exit effect") is unlikely to explain a negative relationship between westward migration and Communist votes. If anything, the departure of liberalminded voters to the West should increase, not decrease, the share of votes for the Communist Party (our main dependent variable). Political self-selection at the community level (i.e., individuals from politically liberal communities being more inclined to migrate to the West), however, is more serious an issue. To address this problem, we first control for electoral preferences before migration started. By conditioning on pre-migration election results, we effectively analyze the change in Communist votes between 1998 and 2009 at the community level and can therefore rule out any time-constant confounder including time-constant electoral preferences. Turning to time-varying confounders, we adopt a stepwise identification strategy. First, we control for a wide range of pre-migration community characteristics. Most importantly, we control for the drivers of early emigration to the East and West, since the first migrants played a crucial role for the destination choice of subsequent migrants from the same communities. ${ }^{4}$ We also control for community-specific economic shocks as measured by satellite data on night-time light intensity. Second, we only evaluate the relationship between migration and voting patterns within districts and show that our point estimates are robust to including fixed effects for increasingly smaller geographical areas. Third, we run a number of falsification tests. Notably, we show that communities with westward and eastward migration followed the same trends in electoral preferences around the time and a few years after migration started and that it is only after enough time had passed that they started to diverge. This is consistent with the time pattern of international communications and, therefore, with an interpretation of the results in terms of information transmission (as we document in Section 6).

\footnotetext{
4 The two main drivers were access to ethnic networks and proximity to the border with Romania. The presence of a Russian minority in a community facilitated early emigration to Russia while being closer to a Romanian border-crossing facilitated emigration to the West (because cross-border interactions provided Moldovans with access to Romanian migrant networks in Western Europe in the late 1990s).
} 
Our main result is a strong and robust effect of migration patterns on electoral preferences and outcomes. Moreover, the magnitude of the effects is large. According to our baseline specification, a one percentage point increase in the community prevalence of westward migration reduces the Communist vote share by about 0.6 percentage points. This result is remarkable as it suggests that the "exit effect" is more than offset by political spillovers from abroad. For example, if we assumed that all migrants to the West would have voted for the opposition in the 2009 elections, our point estimate implies that a one percentage point increase in the prevalence of westward migration would reduce the Communist vote share among those who stay behind by 1.1 percentage points. In addition, the total effect is large. Counterfactual simulations conducted in Section 5.3 suggest that westward migration has been decisive in tilting the results of the 2009 elections that brought about the end of the Communists' rule.

We also find suggestive evidence that the effect of emigration works through information transmission and cultural diffusion channels. ${ }^{5}$ The effects of westward migration are most pronounced in communities in which a large share of the population grew up during the Soviet era or has relatively low levels of education, that is, where information and norms from the West are likely to have the largest informational value. We also document heterogeneous effects across Western destinations, with the effect of westward migration being driven by emigration to the subset of European countries with the highest democratic standards. Finally, we complement our community-level analysis with an individual-level analysis using data from two sources: the Moldova Political Barometer, a political opinion survey with direct information on individual preferences on social issues, and an exit poll survey conducted during the elections of 2010, which included a migration module that we commissioned for this study. The results show that the observed change in electoral preferences is accompanied by a change in political preferences and support our interpretation in terms of information transmission and cultural diffusion channels.

Related literature. The paper builds on three strands of literature. First, there is growing evidence that diaspora networks promote bilateral exchanges of goods, capital, and ideas. ${ }^{6}$ Migration has also

\footnotetext{
5 Monetary remittances are unlikely to drive our destination-specific results because a dollar received from the West should have similar monetary effects as a dollar received from the East. Other research suggests that remittances may result in a worsening of governance at home. E.g., Abdih et al. (2012) argue that politicians may withhold public funds from remittance-receiving communities and appropriate these resources for their own purposes. We discuss monetary remittances and other potential channels in Section 6.

${ }^{6}$ Docquier and Rapoport (2012) review this literature with a focus on high-skilled migration. See also Kerr (2008) on the diffusion of innovation.
} 
been shown to contribute to the transmission of social norms such as fertility behavior. ${ }^{7}$ The literature on migration and political institutions includes macro papers capturing the overall effect of emigration on democracy and micro papers in different contexts. In an influential paper, Spilimbergo (2009) uses cross-country comparisons to show that foreign-trained individuals promote democracy in their home countries, but only if foreign education was acquired in a democratic country. Docquier et al. (2011) extend the analysis to migration in general and find that openness to migration as measured by the total emigration rate contributes to improved institutional quality. At a micro level, Batista and Vincente (2011) document that households in Cape Verde with a migrant abroad, particularly those with a migrant to the US, have a higher demand for political accountability. PérezArmendáriz and Crow (2010) find that individuals in Mexico in households with a migrant in the US or Canada are more likely to vote. Chauvet and Mercier (2013) also focus on voter turnout and report a similar result for Mali. Pfutze (2012) studies Mexico's local elections of 2000 and shows that municipalities with many migrants in the US are more likely to vote for opposition parties. We add to this literature by being first to document destination-specific political spillovers on real political outcomes and by drawing causal inference from a quasi-experimental setting. In addition, we provide suggestive evidence that the observed effects likely work through the diffusion of information and of norms from abroad.

Second, recent work from sociologists, anthropologists, and economists shows that crossing borders and being exposed to new socio-political environments can significantly affect an individual's attitudes, beliefs, and values, including political preferences (Barr and Serra, 2010; Berry, 1997; Cameron et al., 2012; Cain et al., 1991; Luttmer and Singhal, 2011; Shain, 1999; White et al., 2008). ${ }^{8}$ Clingingsmith et al. (2009) analyze the social consequences of the Muslim pilgrimage to Mecca, known as the Hajj. They find that this relatively short experience leads to a persistent change towards more religious tolerance in Pakistani pilgrims' attitudes, beliefs, and practices at home. Relatedly, institutions can have profound effects on people's political preferences and attitudes. For example, Alesina and Fuchs-Schuendeln (2007) show that 40 years of Communist rule made East Germans significantly more favorable to government intervention than their West German compatriots. These differences are long-lasting: while the German reunification led to a convergence of preferences between the East and the West, the convergence process is far from being complete. In the same

\footnotetext{
${ }^{7}$ On fertility, see Fargues (2007), Beine et al. (2013), or Bertoli and Marchetta (forthcoming).

8 Careja and Emmenegger (2012) and Fidrmuc and Doyle (2004) study migrant assimilation with regard to political attitudes in the context of Eastern Europe.
} 
vein, Aghion et al. (2010) show that corrupt governments lower levels of social trust and social capital, which can drive people to demand more regulation and more redistribution (i.e., bigger governments). They find that former socialist countries such as Russia, Slovenia, East Germany and Bulgaria exhibit the highest levels of distrust among people and that those same people express the strongest support for government control of firms, wages and prices. We extend this literature by showing that even indirect exposure (through contacts with migrants) to new social norms and information can trigger significant changes in political attitudes.

Third, recent research has documented the importance of media access for electoral outcomes. DellaVigna and Gentzkow (2010) conclude that access (or non-access) to a diverse set of news media can have a substantial effect on election results. In this strand of literature, the study most related to ours is Enikolopov et al. (2011). The authors find that access to an independent TV channel in Russia reduced the share of votes for Vladimir Putin's ruling party by eight percentage points. In the context of Moldova, we find evidence that new information - transmitted through migrants in our case - can indeed have large political effects. ${ }^{9}$ This suggests that in a globalized world with low communication costs, migration and media exposure can be complementary vectors of democratization.

\section{Moldova as an ideal case study}

\subsection{Political background}

Moldova is a formal parliamentary democracy. The country gained independence from the Soviet Union in 1991 and has been politically stable besides a four-month war on the breakaway region of Transnistria in $1992 .{ }^{10}$ Since independence, the country saw seven parliamentary elections: 1994 , 1998, 2001, 2005, 2009 (April and July), and 2010.

Shortly after independence, the Communist Party was banned. Nevertheless, state-oriented parties, in particular the Socialist Party and the Agrarian Party, firmly dominated politics in the mid-1990s. The Communist Party was re-allowed to enter the political stage at the end of the 1990s. After the economic hardship that followed the Russian financial crisis, the Communists won a landslide

\footnotetext{
9 Access to media can have effects on other socio-economic outcomes, too. E.g., Jensen and Oster (2009) show that the introduction of cable television improved women's status in rural India through the diffusion of more equitable gender attitudes and values.

10 Transnistria is a small strip of land to the East of the Dniester River, which is now effectively a Russian protectorate. It is not included in our analysis.
} 
victory in the snap elections of 2001 by promising a strong hand and Soviet-era living standards. It was the first time a Communist-Leninist party returned to power via democratic means also because large parts of the population were disappointed with democracy. As of November 2001, nearly 60\% agreed with the statement that "only one political party should exist in Moldova", according to the Moldovan Political Barometer (see Section 6.1). In the years that followed, the Communists installed what some regard as full-fledged authoritarianism (Mungiu-Pippidi and Munteanu, 2009). Moldova's Freedom House scores worsened, the judiciary lost parts of its independence, and the freedom of the press gradually eroded (Quinlan, 2004). ${ }^{11}$ Despite some reforms and the adoption of a new, more EU-friendly foreign policy agenda in the mid-2000s, the Communist Party has remained a largely nationalist and state-centered formation, nostalgic of Soviet times.

The elections of 2009 and 2010 mark a watershed in Moldova's political history. In April 2009, the Communist Party failed to win the three-fifths parliamentary majority necessary to elect the country's president. In addition, one day after the elections, protests erupted, following allegations of vote fraud. ${ }^{12}$ Anti-government protestors took to the streets, looted the parliament and raised flags of the European Union on several government buildings. Lacking a presidential majority, the parliament was dissolved and new elections were held in July 2009. The result was the electoral victory of the opposition "Alliance for European Integration", a four-party coalition that formed a new government. Because the Alliance also lacked a presidential majority, another election was held in November 2010, resulting in further losses for the Communist Party. Since then, the European Alliance has consolidated its power, elected a president, and started to implement economic and political reforms. A recent progress report by the European Commission (2012) highlights that Moldova has improved in many areas, including institutional quality, freedom of the press, and investment climate. ${ }^{13}$ The country also topped the list of reformers in the World Bank's 'Doing

\footnotetext{
${ }_{11}$ Remarkably, however, parliamentary elections in this period continued without manipulations (OSCE, 1998, 2001, 2005, 2009).

${ }^{12}$ Although there have been no reports of grave irregularities during the parliamentary election of July 2009, we cannot fully dismiss the possibility of minor vote fraud. However, for vote fraud to explain our findings it should be systematically correlated with migration patterns. More specifically, the incumbent Communist Party should have been less able to manipulate votes in communities with high levels of westward migration and more able to do so in communities with high levels of eastward migration. This assertion would, however, only strengthen our argument that electoral and political preferences are affected by emigration.

${ }^{13}$ E.g., Freedom House states that "Moldova's civil liberties rating improved from 4 to 3 due to a more balanced and diverse media environment, a reduction in government hostility toward civil society groups, and a lack of interference with political gatherings ahead of the November 2010 parliamentary election" (http://www.freedomhouse.org/report/freedom-world/2011/moldova). Similarly, Moldova's Press Freedom score as reported by Reporters Without Borders increased from 22 in 2008, ranked 98 worldwide, to 16 in 2011, ranked 53 worldwide (http://en.rsf.org/spip.php?page=classement\&id_rubrique=1043)
} 
Business' Report 2012 (World Bank, 2012). In line with political scientists (Marandici, 2010; Crowther, 2011), we interpret voting against the Communist Party (i.e., for an opposition party) as voting for political and democratic change.

\subsection{Quasi-experimental setting}

Several factors make Moldova a well-suited case to identify destination-specific political spillovers of emigration. First, information transmitted by migrants from the West is likely to play a large role in shaping political attitudes and electoral preferences in Moldova. During Soviet times, Moldova was virtually cut off from the rest of the world and had little exposure through migration, travel, media, or books. Large parts of the population were exposed to decades of anti-capitalist, anti-Western propaganda. Until 2009, Moldovans had only limited access to free media. Television was by far the most important source of information, while the internet, radio, and print media played only a subordinated role. ${ }^{14}$ The three main television channels were state-controlled throughout the 2000 s (Moldova 1, NIT and Prime TV). They did not provide independent coverage and focused on countries of the former Soviet Union. ${ }^{15}$ Indeed, until today, "Vremya", a direct successor of the main news show of the USSR, remains the most popular news show in Moldova (Open Society Foundations, 2012). Moldovans receive no terrestrial signal of Western TV (unlike in Albania or Communist Eastern Germany) ${ }^{16}$ and only few households can afford cable subscriptions or a satellite dish to receive foreign TV channels, especially in the countryside (Open Source Center, 2008). As a result, large parts of Moldova's population have not had access to unbiased information and have been systematically misinformed (IDIS Viitorul, 2009). In 2005, only 15\% of respondents agreed to the statement that "media are free [...] with no government censorship" according to the Moldovan Political Barometer.

The dire media landscape may be one reason why most Moldovans were politically passive and uninformed during much of the 2000s. The 2002 World Value Survey finds that 53\% of the population was not interested in politics, $55 \%$ said they would never participate in lawful

\footnotetext{
$1471 \%$ of respondents in the 2005 Moldovan Political Barometer stated that television was their main source of political information while $50 \%$ also stated that television was the source they trusted most (see also Open Source Center, 2008). Internet usage has been negligible until very recently. In 2008, only three percent of the population had access to the internet, most of them living in Chisinau (Open Society Foundations, 2012).

15 Moldova 1 and NIT were under direct or indirect control of the state (i.e., the Communist Party), while Prime TV relays the program of the Russian state television ORT. At the same time, small opposition channels like ProTV were subject to continuous intimidation by the government (IJC, 2009).

${ }^{16}$ Braga (2007) finds that Albanians who live in regions exposed to Italian TV are more likely to emigrate.
} 
demonstrations, and less than 3\% were members of a political party. Toka and Popesku (2007) further show that in international comparison, Moldovan voters were very uninformed about the political situation of their country, particularly in rural areas.

At the same time, all available evidence suggests that information transmitted by migrants has become increasingly important for those left behind. More than 90 percent of emigrants in 2008 communicated with their families at least once a month, more than two thirds of them even at least once a week (Luecke et al., 2009). Virtually all migrants (97\%) used the phone for this purpose, while email or internet telephony played no important role. Figure 1 shows that the volume of incoming calls to Moldova steadily increased with the number of migrants until 2006 but skyrocketed afterwards, most likely as a result of lower communication costs. The growth in cross-border telephony is particularly large for main migrant destination countries such as Italy. According to bilateral data from Telegeography, calls from Italy to Moldova increased from close to zero in 1998 (3 million minutes) to 150 million minutes in 2009. This is equivalent to almost 3,000 minutes per migrant in Italy per year, or around 60 minutes per week on average, which suggests a very intense exchange between migrants and their home communities. ${ }^{17}$ In addition, migrants frequently visit their families in Moldova, on average twice a year (Luecke et al., 2009).

Second, emigration to Western Europe started only in the late 1990s. This allows us to control for community characteristics and voting patterns before emigration took off. Large-scale emigration took off only after 1998, when Moldova was severely and unexpectedly hit by the Russian financial crisis. As a result of the crisis, Moldova's currency depreciated sharply, agricultural exports froze, and output fell by 32.5\% year-on-year (Radziwill et al., 1999). All parts of the population were adversely affected and Moldovans started to emigrate in large numbers.

The shift from low (virtually zero) migration prevalence to high migration prevalence is apparent from Figure 1, which is based on data from the Moldovan Labor Force Survey available from 1999 onwards. The same trend is observable using immigration figures of the main destination countries. The figures confirm that Moldova had very little out-migration throughout the 1990 s. $^{18}$ As of 1998, for example, only 15 Moldovan immigrants were officially registered in Italy, but this number increased to 40,000 by 2004. A similar explosive growth in Moldovan immigration occurred in other

\footnotetext{
${ }^{17}$ Data on the volume of bilateral calls does not include internet telephony.

18 It should be noted, however, that large parts of Moldova's Jewish community emigrated to Israel, the United States, and Germany directly after the collapse of the Soviet Union (1991 and 1992). Jewish migrants left permanently with their families and did not maintain strong ties with Moldova. This small wave of emigration, therefore, differs substantially from the subsequent wave of labor migration that started in the late 1990s (Moşneaga et al., 2006).
} 
popular destination countries such as Greece, Portugal and Spain. ${ }^{19}$ By 2009, more than 300,000 Moldovans were estimated to have left the country on a temporary or permanent basis, out of a population of 3.6 million (Luecke et al., 2007 and 2009). ${ }^{20}$

Third, unlike most migrant-sending countries, Moldova has two main migration corridors with destinations of very different democratic traditions and political ideologies. As of 2004 , about $40 \%$ of emigrants had left for democratic countries in Western Europe, while $60 \%$ had left for less democratic countries in the East, in particular Russia (see Table 1). This divergence allows us to identify destination-specific political spillovers, as migrants to Western Europe are likely to transmit different information and norms than migrants to Russia.

Whether a community sends migrants to the West or East largely depends on the destination choice made by the first migrants from that community. This is because migrant networks induce a high degree of path dependency in migration flows by providing information on jobs abroad and lowering the costs of migration for subsequent migrants. As a result, migrants from a specific origin tend to cluster at specific destinations (Munshi, 2003; McKenzie and Rapoport, 2010). This observation also holds for Moldova, where local migrant networks are a main driver of individual migration decisions (Görlich and Trebesch, 2008). ${ }^{21}$ Two factors primarily influenced the destination choice of the first migrants who left Moldova at the end of the 1990s. The first factor was access to ethnic networks (Krause, 2000; Moşneaga, 2009): Russian and Gagauz minorities in a community facilitated the departure to Russia and Turkey, while ethnic Moldovans could draw on Romanian ancestry and successfully apply for a Romanian passport, which considerably eased departure towards Western Europe. The second factor was the web of personal contacts that resulted from trading across the Moldovan-Romanian border (Sandu et al., 2006). ${ }^{22}$ The Romanian border had been closed during Soviet times and its opening in the early 1990s offered ample arbitrage opportunities. The resulting

\footnotetext{
${ }^{19}$ As of 1998, the number of Moldovan residents in Portugal, Greece and Spain was close to zero (given as 0, 944 and 96 , respectively), but in all three countries the numbers increased drastically afterwards. Data on Moldovan immigrants in Italy is from the Ministero Dell'Interno, for Portugal from the Instituto Nacional de Estatistica, for Greece from the Hellenic Statistical Authority and for Spain from the OECD. For Russia, no statistics on Moldovan immigration is available.

20 In comparison, internal migration is much less widespread. According to the 2004 population census, only six percent of the population changed their residence within Moldova in the five-year period prior to the census. The vast majority of them moved to Chisinau or Balti, the only two major cities in the country.

${ }^{21}$ Network effects have resulted in a high concentration of migration flows to a few main destinations. In 2006 , three quarters of Moldova's migrant population were located in just ten different cities abroad including Moscow, Rome, St. Petersburg, Milan and Paris (Luecke et al., 2007).

22 Cross-border trade was halted when Romania joined the European Union in 2007. The result was stronger border enforcement and stricter visa and customs regulations (Arambaşa, 2009).
} 
"shuttle trade" flourished and gave Moldovan merchants access to a growing network of Romanian migrants who were working in Western Europe (Michalon, 2009; Arambaşa, 2009). Appendix 1 shows supporting evidence and analyzes the determinants of migration patterns in detail.

For identification, we exploit the fact that migration patterns vary greatly across observationally similar and neighboring communities. Figures 2 and 3 show the distribution of overall migration prevalence and the share of westward migrants among all migrants. Figure 2 shows the observed levels and Figure 3 the residual variation that is left after controlling for observable pre-migration community characteristics (which are described in detail in Section 4.3), in particular the factors that drove the destination choice of the first migrants. While there is some spatial clustering of observed migration patterns (Figure 2), no systematic spatial pattern exists for the residual variation (Figure 3). It thus seems that small differences in pre-migration community characteristics can bring about large differences in migration patterns. This finding is consistent with the idea that, conditional on observables, there is a considerable quasi-random component in the direction of early migration flows that set the path for subsequent migrants.

\section{Data and stylized facts}

Our main outcome of interest is the share of Communist votes in the parliamentary election of July 2009, which marked the fall of the Communist government. The main unit of analysis is the community and we consider all Moldovan communities except those in the breakaway region of Transnistria. Communities are typically small and rural, with an average population size of 3,793 inhabitants (and a median of 2,126 inhabitants). Only 45 out of the 848 Moldovan communities in our sample are classified as urban. There is little variation in economic activity across communities and most areas focus on agricultural production according to data from the Moldovan Ministry of Economy and Trade. Vote shares at the community level are based on the official election results as documented by the Central Election Commission of Moldova. We only consider votes cast by the resident population in Moldova and exclude the few out-of-country votes cast by migrants in Moldovan embassies and consulates abroad. ${ }^{23}$ It is important to note that the electorate votes for political parties, not individual candidates. Parties publish the list with the names of their 103 candidates in advance (the parliament has 101 seats, 2 candidates are in reserve). The candidates are

\footnotetext{
23 In the parliamentary election of July 2009, out-of-country voting was possible in 33 Moldovan embassies and consulates. However, only 17,544 migrants invested the time and effort to vote. As out-of-country votes are listed separately, they can be easily excluded for the purpose of our analysis.
} 
the same across communities and a member of parliament does not represent a specific territorial constituency.

The main explanatory variables are the prevalence of emigration to the West and East measured as the share of westward and eastward migrants in percent of the total population in each community. Information on emigration comes from the 2004 population census. Moldova's population census of 2004 is one of the very few censuses in the world that provides detailed information on individuals who are temporarily or permanently absent and reside abroad. Absent persons include individuals who may have lived abroad for several years as long as they maintained family relations with the household of origin. The census definition should provide an accurate picture of migration patterns up to 2004 as it was highly unusual for entire families to emigrate in the early 2000s (Luecke et al., 2009).

We classify destination countries as West or East based on their democracy levels. Countries with a Polity IV score higher than Moldova's are defined as Western countries. Countries with a score lower or equal to Moldova's are defined as Eastern countries. This classification closely reflects destination countries' geographical position relative to Moldova, hence the terms West and East. The most important destinations in the West are Italy (mostly Northern Italy, see Luecke et al., 2007) and other Roman-language countries; the most important destination in the East is by far Russia (see Table 1).

Figure 4 correlates the overall prevalence of emigration in 2004 with the share of Communist votes in the parliamentary election of July 2009. The scatter plot does not reveal any relationship between the level of emigration and Communist votes at the community level. The picture looks very different when we distinguish between emigration to the West and East. Figure 5 correlates the prevalence of emigration to the West with the share of Communist votes. Now the scatter plot reveals a clear negative relationship. Higher levels of emigration to the West are related with less electoral support for the Communist Party (i.e., more electoral support for more democratic and proEuropean opposition parties). Exactly the opposite is true for emigration to the East. As Figure 6 shows, higher levels of emigration to the East are related with more electoral support for the Communist Party (i.e., less electoral support for more democratic, pro-European opposition parties). 


\section{Empirical strategy}

\subsection{Basic specification}

Our basic empirical specification to estimate the relationship between migration patterns and Communist votes is

$$
\text { Communist }_{i j 2009}=\alpha+\beta W e s t_{i j 2004}+\gamma \text { East }_{i j 2004}+X_{i j}^{\prime} \delta+\varepsilon_{i j}
$$

where $i$ indexes communities and $j$ districts. The dependent variable Communist $_{i j 2009}$ is the share of votes for the Communist Party in the parliamentary election of July 2009. West $t_{i j 2004}$ and East $_{i j 2004}$ denote the share of a community's population that has emigrated to the West and to the East as measured by the population census in $2004 . X^{\prime}{ }_{i j}$ is a vector of control variables at the community level which we introduce in detail below. Our main coefficients of interest are $\beta$ and $\gamma$, the estimated relationship between emigration to the West or East and Communist votes. In accordance with destination-specific transfers of information and norms, we expect $\beta$, the coefficient of the prevalence of emigration to the West, to be negative and $\gamma$, the coefficient of the prevalence of emigration to the East, to be positive. However, we expect the relationship between eastward migration and Communist votes to be weaker than for westward migration, as the socio-political environment of Moldova is more similar to the socio-political environment in the East than in the West. We estimate the model with ordinary least squares and cluster standard errors at the district level to take into account that election results of communities in the same district are likely to be correlated.

To arrive at causal estimates of the effect of migration patterns on Communist votes, the ideal experiment would not only randomize who migrates, but also to which destination. Doing so would solve the problem of self-selection of individuals into migration and destinations, in particular along political dimensions. The coefficients of westward and eastward migration would then provide unbiased and causal estimates of destination-specific political spillovers on those who stay behind. Such an experiment is, however, practically not feasible.

To deal with the observational nature of our data, we need to address two main challenges for identification: first, political self-selection of migrants, discussed in Section 4.2, and second, confounding factors that drive both migration and voting patterns, discussed in Section 4.3. Based on our argument above, potential problems related to political self-selection and confounding factors should be of particular importance for the destination choice of the first migrants who set the path for subsequent migrants. However, they should be of less importance for the destination choice of 
the bulk of the migrants who followed suit. Path dependency is also what makes us confident that migration patterns in 2009 are very similar to those observed in 2004.

\subsection{Political self-selection}

Those who choose to migrate arguably differ in their electoral preferences from those who stay behind. At the same time, individuals who migrate to the West may differ in their electoral preferences from individuals who migrate to the East. To understand the implications of political self-selection, one should distinguish between political self-selection at the level of individuals and political self-selection at the level of communities.

At the level of individuals, political self-selection refers to the exit effect described by Hirschman. If migrants are relatively less supportive of the Communist Party than the average voter in a community, then their departure will increase the Communist vote share in that community as the local electorate loses potential opposition voters. In other words, the exit effect would drive the coefficients of westward and eastward migration upwards because they will capture both political spillovers on those who stay behind and the exit of opposition voters from the electorate. By contrast, if migrants are relatively more supportive of the Communist Party than the average voter, their departure will decrease the Communist vote share and drive the coefficients of westward and eastward migration downwards. A similar argument can be made if migrants' destination choice is perfectly aligned with their electoral preferences: opposition voters would leave for the West and Communist voters for the East. The departure of migrants to the West would then be associated with an increase in the share of Communist votes and the departure of migrants to the East with a decrease in the share of Communist votes - which is exactly the opposite of what political spillovers from the West and East would predict.

We cannot observe how migrants would have voted in the parliamentary election of July 2009 had they not migrated. Without controlling for the pre-migration electoral preferences of migrants, however, the coefficients of westward and eastward migration also pick up the change in the composition of the electorate that is due to the departure of voters. Depending on how migrants are politically self-selected, the coefficients therefore provide a biased estimate of destination-specific political spillovers. ${ }^{24}$

\footnotetext{
${ }^{24}$ There exists little evidence on the political self-selection of migrants in Eastern Europe. Gugushvili (2011) studies political attitudes and emigration intentions in the former Soviet republics of Armenia, Azerbaijan, and Georgia. He finds that individuals who are dissatisfied with the democratic development of their home country are more likely to consider moving to Western Europe.
} 
What do we know about the political self-selection of Moldovan migrants? First, emigration from Moldova is typically motivated by economic, not political, considerations (Luecke et al., 2007). Nevertheless, migrants are likely to be less supportive of the Communist Party than the general population, mainly because, being young and educated, they share the demographic profile of opposition voters. This is particularly true for migrants to the West, who are younger and more educated than the average migrant (Luecke et al., 2007). The average migrant is 35 years old, which is closer to the average age of opposition voters (40 years) than the average age of Communist voters (48 years). Likewise, more than 60 percent of the migrants have completed more than compulsory secondary education, compared to 65 percent among opposition voters and only 48 percent among Communist Party voters. ${ }^{25}$ Second, the share of Communist votes cast by migrants at Moldova's embassies abroad was only 12 percent in 2005, much lower than the overall Communist vote share of 46 percent. Similarly, in July 2009, the share of Communist votes among migrant votes was nine percent compared to an overall share of 45 percent. ${ }^{26}$ At least for westward migration, it is therefore reasonable to conclude that the exit effect in Moldova runs into the opposite direction of potential destination-specific political spillovers. At the level of individuals, political self-selection will thus make the coefficient of westward migration a conservative estimate of political spillovers from abroad.

At the community level, political self-selection of migrants is a more serious concern. If individuals from more liberal communities tend to migrate to the West and individuals from more Communist communities tend to migrate to the East, the coefficients of westward and eastward migration would merely reflect a spurious correlation, but not a causal estimate of destination-specific political spillovers.

To address this problem, we exploit the fact that there was hardly any emigration before 1999. We can control for the electoral preferences of each community before migration took off by using the election results from the parliamentary elections of 1994 and 1998, which were the first national elections after Moldova's independence in 1991. Both elections were widely regarded as free and fair (OSCE, 1998). The parliamentary election of 1998 took place just a few months before the unexpected Russian financial crisis hit Moldova in late 1998 and triggered the first wave of

\footnotetext{
${ }^{25}$ Migrants' demographic characteristics come from the 2008 Labor Force Survey. The demographic characteristics of Communist and opposition voters come from the official exit poll of the parliamentary election of July 2009.

${ }^{26}$ No data is available for the parliamentary election of 2001. It should be noted that the number of votes cast abroad is only a small fraction of the estimated number of Moldovans residing abroad. The results are therefore unlikely to be representative of the migrant population.
} 
emigration. For each of the parliamentary elections of 1994 and 1998, we control for the communityspecific vote share of the four major parties. In both elections, more than 70 percent of the electorate cast their vote and the four major parties accounted for more than three quarters of all votes. We should therefore capture the broad spectrum of pre-migration electoral preferences at the community level. The shares of Communist votes in 1998 and 2009 are highly correlated (at 0.74). The large persistence suggests that pre-migration electoral preferences are a meaningful measure of a community's general electoral preferences. We also include the voter turnout in 1998 as a proxy for the general interest in politics (information on voter turnout in 1994 is not available at the community level). By conditioning on pre-migration election results, we effectively analyze the change in Communist votes between 1998 and 2009. Hence, we can rule out that time-constant electoral preferences explain the relationship between migration and voting patterns. ${ }^{27}$

We find little evidence for political self-selection of migrants at the community level. Table A1 in the appendix shows that, conditional on observable community characteristics, pre-migration electoral preferences are not systematically associated with the size and direction of migrant flows at the community level. In particular, we do not find that communities with a pre-migration preference for democratic opposition parties send more migrants to the West. Similarly, we do not find that communities with a pre-migration preference for the Communist or Socialist Party send more migrants to the East.

\subsection{Confounding factors}

The second main challenge for identification are confounding factors that drive both migration and voting patterns. By looking at changes in Communist votes over time, we already eliminate any confounders with time-constant effects. Our discussion therefore focuses on the role of time-varying confounders. For instance, one may be concerned that nation-wide shocks like the Russian financial crisis or the process of economic transition hit some communities harder than others. Similarly, there may have been some region-specific shocks like natural disasters or the emergence of new sociopolitical movements. These heterogeneous shocks may then have affected not only electoral preferences, but also migration flows to the West or East.

\footnotetext{
${ }^{27}$ Note that in an econometric sense this is only true if we estimate our specification in first differences, which we do not do in our main specification. The reason is that we prefer to condition not only on the initial share of Communist votes but also on the vote share of other parties to capture the heterogeneity of initial political preferences. As part of the robustness checks we also estimate a model in first differences.
} 
We employ three strategies to deal with time-varying confounders. First, we use fixed effects for Moldova's 35 districts to eliminate any time-varying (and time-constant) heterogeneity at the district level. In other words, we only evaluate the relationship between migration patterns and Communist votes for communities within the same district. Moldovan districts are very small. The average district covers only 967 square kilometers (373 square miles) and is home to 26 communities. In addition, Moldovan districts follow the same boundaries as the former regional administrative units of the Moldavian Soviet Socialist Republic (raions). In Soviet times, raions were the basic territorial unit around which economic life was organized. District-level fixed effects should therefore capture many of the potential confounders along geographical and economic dimensions that may have occurred after the collapse of the Soviet Union. They should also account for the proximity of certain districts to the border with Romania and the Ukraine, which may be subject to cross-border spillovers not related to migration.

Second, we control for a wide range of community characteristics. The idea behind this strategy is that observationally similar communities within the same district should be subject to similar shocks and should also respond to these shocks in a similar way. In general, Moldovan communities are remarkably similar, with no major economic differences, particularly within the same district. The main reason for this similarity is that Moldova is small (about the size of Maryland) and was planned to be a rural economy with no industrial capacity during Soviet times. Moldova's only industrial activities are located in the breakaway region of Transnistria, which is not included in our sample. That said, we try to control for as many dimensions of community heterogeneity as possible. We use census data to control for population size, age structure, and the skill level and distribution of the adult population. ${ }^{28}$ Most importantly, we also control for the two main drivers of the destination choice made by the first migrants: access to ethnic networks and the distance to the Romanian border. Specifically, we use the population shares of the four most important ethnic minorities (Ukrainians, Russians, Gagauz, and Bulgarians, with Moldovans being the reference category) as well as the degree of ethnic fractionalization. As ethnic composition may have played a role in the evolution of electoral preferences, too, we also include squared terms of the different ethnicities' population shares. The distance to the Romanian border is measured by the distance to the nearest Moldovan-Romanian border crossing that was open in 1998 (Marcu, 2009). We also include a

\footnotetext{
28 All demographic data come from the population census in 2004. They are measured for the original overall population including migrants. Therefore, our demographic variables are generally representative and not affected by emigration. In theory, emigration may have affected enrolment of children in schools. In practice, however, emigration should not have had any meaningful effect on overall educational attainment in 2004 - just five years after migration took off in Moldova.
} 
dummy for district capitals and a dummy for the only two major cities of Moldova, the capital Chisinau and Balti. As a proxy for remoteness, we use a community's distance to their district capital, since these have always been the economic and political center of a district.

Third, we capture community-specific economic shocks using high-resolution satellite data on nighttime light intensity. This approach follows Henderson et al. (2012), who show that light intensity as measured from outer space is a meaningful proxy for local economic activity on the ground. This correlation is due to the fact that almost all consumption and production activities at night require lights. To compensate Moldova's lack of economic data at the community level for the 1990s and early 2000s, we therefore use satellite images from the Defense Meteorological Satellite Program's Operational Linescan System. These satellites observe every location on the planet every night at some time between 8.30 and $10 \mathrm{pm}$. Scientists at the National Geophysical Data Center then clean the recorded images from clouds and natural light sources, so that the remaining light is mostly produced by human activity. In a last step, all valid observations for a given year are averaged and light intensity is reported in a grid of pixels sized approximately 0.55 square kilometers $(0.21$ square miles) (see Henderson et al. 2012, for further details).

For Moldova, we average the light intensity of all pixels on the administrative territory of each community for 1992, the first year for which satellite images are available, and 1999, the year following the Russian financial crisis. The difference in light intensity between 1992 and 1999 proxies the severity of a community's economic shock caused by the economic transition after Moldova's independence in 1991 and the Russian financial crisis. Figure A1 in the appendix shows the drastic changes in night-time light over that period. In 1992, many parts of the country were well-lit at night. By 1999, however, most Moldovan communities had become dark. Over the same period, Moldova's gross domestic product had fallen by 40 percent. Table A1 in the appendix shows that the adverse economic shocks of the 1990s indeed pushed many Moldovans abroad. Communities with a reduction in night-time light intensity between 1992 and 1999 had a significantly higher prevalence of emigration in 2004. Importantly, however, economic shocks cannot explain the direction of migration flows to the West or the East. We also find that communities that experienced a steeper economic decline during the 1990s were more likely to vote for the Communist Party in the parliamentary election of 2001 (results available upon request). Finally, Table A2 in the appendix demonstrates that night-time light intensity is indeed a good proxy for economic activity at the community level. Light intensity is a highly significant predictor of local per-capita tax revenues, 
unemployment rates and the per-capita number of shops in 2009, a year for which economic indicators at the community level are available.

\section{Results}

\subsection{Migration patterns and electoral preferences}

Table 3 summarizes the main results from the econometric analysis. Full regression results are provided in Table A3 in the appendix. The first three columns investigate the relationship between migration patterns and Communist votes in the parliamentary election of July 2009. The columns gradually expand the set of control variables and check the robustness of our results against potentially important confounders.

Column 1 controls for community heterogeneity in terms of size, location, as well as demographic and ethnic composition. The results are suggestive of destination-specific political spillovers. Communities with more westward migration vote significantly less for the Communist Party. The coefficient is large: the departure of one percent of the community population to the West reduces the share of Communist votes by about 0.7 percentage points. This result is remarkable as it implies that the departure of a (presumably) largely non-Communist electorate to the West may be more than offset by political spillovers from abroad. We find the opposite, but weaker association for emigration to the East. A one-percentage-point increase in the prevalence of eastward migration increases the share of Communist votes by about 0.4 percentage points. ${ }^{29}$

Column 2 additionally controls for the pre-migration election results for the four major parties in the parliamentary elections of 1998 and 1994 in each community. These variables eliminate any timeconstant heterogeneity at the community level. In particular, they address the concern that communities with generally low (high) support for the Communist Party send more migrants to the West (East). Historical election results are an important predictor of election results more than a decade later. However, controlling for pre-migration election results barely affects the size and significance of the coefficients of westward and eastward migration. This finding reflects the previously discussed evidence that pre-migration election results have no significant effect on the

\footnotetext{
29 Our estimates of the relationship between migration patterns in 2004 and Communist votes in 2009 may be biased upwards as we attribute the effects to the migration prevalence in 2004, which was about 26 percent lower than the migration prevalence in 2009. If we rescale the coefficients accordingly, the coefficient of westward migration is reduced to 0.52 and the coefficient of eastward migration to 0.33 . However, the true bias is likely to be smaller because the magnitude of the marginal effect of emigration on Communist votes decreases with the level of emigration (see Section 6.1).
} 
prevalence of migration to the West or East. Thus, we can rule out that a time-constant confounder including political self-selection at the community level explains the association between migrants' destinations and Communist votes.

Column 3 adds community-specific measures of economic shocks over the course of the 1990s as measured by night-light intensity to the set of control variables. This is our preferred specification and we continue to use it as the baseline specification in the rest of the paper. If economic shocks in the early years of the transition period and in particular as a result of the Russian financial crisis in 1998/1999 shaped the evolution of both migration and voting patterns, their inclusion in the model should change the coefficients of westward and eastward migration. Yet, including night-time light intensity as regressor does not affect the coefficients of interest. This is in line with the previous result that light intensity is not associated with migrants' destination choice. Hence, local economic shocks are unlikely to confound the effect of migration patterns on Communist votes in 2009.

The remaining columns of Table 3 show the relationship between migration patterns and vote shares of the four opposition parties that jointly formed the ruling coalition after the elections. The Liberal Democratic Party and the Liberal Party gain significantly more votes in communities with higher levels of westward migration. And the Liberal Party attracts considerably fewer votes in communities with higher levels of eastward migration. Votes for the other two parties are not significantly associated with migration patterns.

In Appendix 2, we perform a number of checks to assess the robustness of the baseline coefficients of westward and eastward migration. We show that our results are robust to (i) the inclusion of additional control variables such as the demographic characteristics of migrants, (ii) alternative econometric specifications such as estimation in first differences, and (iii) an alternative definition of the "West". In particular, the coefficient of westward migration remains significant and becomes even more negative when we drop Italy, the most important destination of Moldovan migrants in Western Europe. In Section 6.1, we also show that the results are mostly driven by emigration to the most advanced democracies.

\subsection{Testing for time-varying unobserved confounders}

A remaining challenge for causal interpretation is an unobserved time-varying confounder. To be relevant, such a confounder must work at the sub-district level as the district fixed effects already wipe out any time-varying (and time-constant) district-level heterogeneity. In addition, the stability of the coefficients of westward and eastward migration across columns 1 to 3 of Table 3 implies that a 
relevant confounder must be much more strongly associated with migration patterns and Communist votes than election results and economic shocks during the 1990s. Only then could a confounder explain the estimated relationship. To assess this possibility, we propose two tests.

\section{Migration patterns and electoral preferences over time}

The first test for unobserved heterogeneity investigates the relationship between Communist votes and migration patterns over time. If it is the case that migration (and not a confounder) drives our results, westward and eastward migration as measured by the census in 2004 should not be associated with election results around the time when migrants just started to leave Moldova.

The first part of Table 4 examines the relationship between migration patterns and Communist votes in all parliamentary elections since 2001. Of particular interest is the parliamentary election of 2001. It was the first parliamentary election after the Russian financial crisis of 1998/1999, which hit Moldova's economy hard and triggered the departure of the first migrants. And it was the election that brought the Communist Party back to power. In 2001, the level of emigration was still low (see Figure 1) and most of the migrants captured in the census in 2004 had not left yet. Hence, if emigration has a causal effect on election results, there should be no association between Communist votes in 2001 and the prevalence of emigration to the West and East in 2004.

Column 1 shows that migration patterns in 2004 are indeed not significantly related with Communist votes in 2001. Thus, there is no evidence of an unobserved confounder that simultaneously shaped migration and voting patterns. This finding strengthens the common trend assumption of our identification strategy. It also suggests that the destination choice of the first migrants, which laid the basis for the migration patterns in 2004, was not systematically related with the evolution of electoral preferences in the aftermath of the Russian financial crisis.

Migration patterns are not significantly related to Communist votes in 2005 either (column 2), although (and in contrast to 2001) the level of emigration was already high. There may be two reasons for this non-finding. First, at that time, the intensity of communication between migrants and their families and friends in Moldova was still relatively low, at least as measured by the volume of international calls from and to Moldova (see Figure 1). Between 2005 and 2009, however, the volume of international calls increased by a factor of four. The fall in communication costs during that period most likely increased the intensity of communication and facilitated the inflow of information and norms from abroad. Second, the 2005 result does not necessarily indicate the absence of destination-specific political spillovers. As explained above, the coefficients of westward 
and eastward migration reflect both the exit effect and destination-specific political spillovers. At least for westward migration, these two effects go into opposite directions. Hence, it may well be that in 2005, political spillovers were present but they were not yet large enough to overcompensate for the exit effect. This would explain the insignificant relationship between migration and voting patterns. Indeed, if one neutralizes the exit effect by making the extreme assumption that all westward migrants would have voted for the opposition parties (see Section 5.3 for details on the methodology), the coefficient of westward migration becomes significantly negative and its magnitude increases from -0.18 to -1.10 (detailed results available upon request).

It is only in the recent elections of April and July 2009 as well as of November 2010 that migration patterns are significantly associated with voting behavior (columns 3-5). The coefficient (and marginal effect) of westward migration becomes increasingly larger, starting at -0.40 in April 2009 and reaching -0.85 in November 2010. Thus, political spillovers from westward migration appear to be growing over time. This result may indicate that migrants in the West increasingly raised their voice after the disputed elections in April 2009 that marked the political deadlock between the Communist Party and the opposition. Similarly, the coefficient of eastward migration slightly increases from 0.27 in April 2009 to 0.39 in July 2009. However, it is no longer significantly different from zero in November 2010. Thus, if there were political spillovers from eastward migration, they appear to be weaker and are not stable over time.

The second part of Table 4 goes beyond parliamentary elections and investigates the relationship between migration patterns and Communist votes in local elections at the municipality level over the period 1999-2007. The municipal elections of 1999 are particularly suitable to test for the existence of a confounder as it took place in the immediate aftermath of the Russian financial crisis. The set of explanatory variables is the same as in our baseline regression. However, as vote shares are not available at the municipal level, the dependent variable is a dummy indicating whether a Communist mayor was elected. Results from a linear probability model strongly suggest that there were no initial differences in electoral preferences between communities with different migration patterns (column 6). The point estimates of both migration coefficients are very close to zero. The same holds true for the municipal elections of 2003, supporting our common trend assumption (column 7). It is only in the local elections of 2007 that communities with more westward migration diverge and become less likely to elect a Communist mayor. A one-percentage point increase in emigration to the West decreases the probability of electing a Communist mayor by about two percentage points. We find 
no effect of eastward migration (column 8). This result is important as we observe political spillovers of westward migration already before the global financial crisis of 2008.

Overall, the findings reported in Table 4 further limit the range of potentially relevant confounders. Any remaining confounder must have affected migration patterns well before 2004 and electoral preferences only thereafter with a lag of several years.

\section{Spatially concentrated time-varying confounders}

The second test for unobserved heterogeneity builds on the idea that an unobserved confounder would likely be spatially concentrated and affect neighboring communities in a similar way. Indeed, spatial clustering has been observed for changes in political variables such as electoral preferences (Pattie et al., 1997; Kim et al., 2003) as well as for changes in socio-economic variables such as income levels or unemployment rates (see the review by Combes and Overman, 2004). Local fixed effects should at least partially capture a spatially concentrated confounder and therefore lower the estimated coefficients of migration on Communist votes. Local fixed effects should increasingly do so the smaller the geographical area they are based on. By contrast, in the absence of such a confounder, local fixed effects should not significantly affect the size of the estimated relationship.

To test these implications, we introduce local fixed effects that are based on a geographical grid of quadratic cells and are much finer than the district-level fixed effects. We start with cells sized 30x30 kilometers $(18.6 \times 18.6$ miles) and then reduce the cell size to $15 \times 15$ kilometers $(9.3 \times 9.3$ miles $)$. This procedure increases the number of local fixed effects from 35 with district fixed effects to 52 using 30x30 kilometer cells and 162 using 15x15 kilometer cells for the grid. The grid removes any timevarying and time-constant heterogeneity at the grid-cell level. The finer the grid, the more unobserved heterogeneity we therefore expect to capture. Figure A2 in the appendix illustrate the different resolutions of the grid on a map of Moldovan districts. In particular, the 15x15 kilometer cells are much smaller than the average Moldovan district. The average number of communities in each cell is five using the 15x15 kilometer grid and 16 using the 30x30 kilometer grid. The grid thus ensures that the relationship between migration and voting patterns is evaluated comparing only neighboring communities. Compared to our baseline specification that uses district-level fixed effects, the grid should make communities more similar in terms of (i) local labor markets and local economic shocks, (ii) political movements and exposure to political campaigns, (iii) exposure to weather fluctuations or natural disasters, and (iv) local reception of different media channels. To deal 
with the arbitrary boundaries created by the grid, we shift the grid by random distances and iterate the analysis a hundred times.

Table 5 reports the coefficients and standard errors of the first iteration as well as the average coefficient over the 100 iterations for the two grid resolutions. The coefficients of both westward and eastward migration are remarkably robust to the use of fixed effects for grid cells. The average size of the coefficients drops only slightly. We use a simple t-test to compare the differences between the estimated coefficients of westward migration to the baseline coefficient of -0.63 (column 3 of Table 3). In none of the 200 total iterations can we reject the hypothesis that the difference is significantly different from zero. It is particularly remarkable that the size of the estimated coefficients is completely robust to increasing the grid resolution from 30x30 kilometer to $15 \times 15$ kilometer cells. For eastward migration, only nine of the 200 estimated coefficients are significantly different from the baseline coefficient. We are therefore confident that the coefficients of westward and eastward migration are not systematically biased by a spatially concentrated confounder.

The two tests for unobserved time-varying heterogeneity strongly support a causal interpretation of the effects of emigration to the West and East on Communist votes. To challenge a causal interpretation, an unobserved confounder must (i) be time-varying, (ii) much more strongly associated with migration patterns and electoral preferences than election results and economic shocks during the 1990s, (iii) affect electoral preferences several years later than migration flows, (iv) be specific to a community or not affect neighboring communities in a similar way, and (v) account for the opposing effects of westward and eastward migration. While we cannot rule out such a confounder, we consider its existence implausible.

\subsection{How large is the effect?}

\section{Disentangling destination-specific political spillovers from the exit effect}

As discussed above, the coefficients of westward and eastward migration capture both political spillovers on those who stay behind and the exit of migrants from the electorate. This subsection attempts to disentangle the effect of political spillovers from the exit effect. To assess the degree to which the exit effect may bias the interpretation of the migration coefficients as political spillovers, we run the following thought experiment: We make extreme assumptions on how migrants would have voted had they stayed in Moldova. We then send all migrants back to their home communities and add their hypothetical votes to the observed votes of their communities assuming that migrants would have had the same voter turnout as the non-migrant community population. Finally, we re-run 
our baseline specification (column 3 of Table 3) using the hypothetical vote share of the Communist Party as new dependent variable. By definition, the exit effect is now neutralized as migrants remain part of the electorate. As a result, the estimated migration coefficients provide the lower and upper bounds of political spillovers on those who stay behind depending on which assumptions we make on the voting behavior of migrants. We consider three different scenarios, summarized in Table 6 .

In scenario 1, there is no political self-selection: all migrants are assumed to have voted like the average stayer in their home communities in July 2009 (column 1). The coefficients of westward and eastward migration are thus exactly the same as the coefficients of our baseline specification. However, the assumption of no political self-selection is not realistic. Given their demographic profile, migrants, particularly those to the West, are likely to be less supportive of the Communist Party than the average voter. The coefficients should therefore provide an underestimation of political spillovers from the West and an overestimation of political spillovers from the East.

In scenario 2, all migrants would have voted for opposition parties (column 2). Under this extreme assumption, the coefficient of westward migration provides an upper bound for political spillovers from the West because, in contrast to the baseline coefficient, it can no longer be driven upwards by the departure of opposition voters. Indeed, the coefficient of westward migration now drops to -1.11 . This is almost double the magnitude of the baseline coefficient of -0.63 , which still includes the exit effect (i.e. the fact that the Communist vote share increases due to the departure of opposition voters). These two coefficients define the plausible range of the magnitude of political spillovers of westward migration. The emigration of one percent of a community's population to the West reduces the share of Communist votes among those who stay behind by a minimum of 0.63 (if migrants would have voted as the average stayer) and a maximum of 1.11 percentage points (if migrants would have been opposition voters). Our baseline coefficient of westward migration should therefore be interpreted as a conservative estimate of the political spillovers from abroad.

The opposite is true for the coefficient of eastward migration. Under the assumption that all migrants would have voted for opposition parties, the coefficient of eastward migration provides a lower bound for the political spillovers of eastward migration. Because it can no longer be driven upwards by the departure of opposition voters, the coefficient of eastward migration becomes negative and drops to -0.48 , compared to the baseline coefficient of 0.39 . Again, these two coefficients mark the range in which the magnitude of political spillovers of eastward migration is most likely to be located. As the range includes zero, we cannot conclude with certainty that the political spillovers from the East increase the share of Communist votes among those who stay 
behind. What we can conclude, however, is that political spillovers are likely to be much larger for westward than for eastward migration.

For completeness, we also show the unlikely scenario 3 , in which all migrants would have voted for the Communist Party (column 3). Only when we make this unrealistic assumption do we no longer find that political spillovers of westward migration decrease the share of Communist votes.

Overall, this exercise provides strong evidence that political spillovers from emigration to the West indeed reduce support for the Communist Party in migrants' home communities and are no artifact of the compositional change of the electorate. Under reasonable assumptions on the direction and degree of political self-selection of migrants, the baseline coefficient of westward migration is a conservative estimate of the true size of political spillovers from the West. The baseline coefficient of eastward migration may, however, overestimate the size of political spillovers from the East. ${ }^{30}$

\section{Counterfactual election results}

To obtain a better understanding of the quantitative importance of our findings, this subsection performs a simple counterfactual analysis of the effects of emigration on election results in July 2009. Our back-of-the-envelope calculations are based on the point estimates from the baseline specification (column 3 of Table 3). To arrive at nation-wide counterfactual election results, we weigh the predicted election results by the number of votes cast in each community. For simplicity, we assume that migrants would have had the same electoral preferences (vote distribution) and the same voter turnout as their home communities. As we have shown above, this assumption on migrant voting is conservative. We are hence likely to underestimate the true political spillovers of westward migration.

Table 7 presents the observed and counterfactual shares of Communist votes and the resulting changes in the distribution of parliamentary seats for different migration scenarios. The first row summarizes the actual election result, with a vote share of 45 percent for the Communist Party. This translated into 48 out of the 101 seats in Parliament - three seats short of the absolute majority of 51 seats. The remaining 53 seats were distributed among the Liberal Democratic Party, the Liberal Party, the Democratic Party, and the Party Alliance Our Moldova, which were thus able to push the Communists out of power and form a new coalition government.

\footnotetext{
30 These results are also useful to assess the potential consequences of return migration. If anything, the coefficients are likely to underestimate the electoral consequences of emigration in case of return migration.
} 
The first part of the counterfactual analysis holds the level of migration constant, but changes the direction of migration flows. We first shift all migrants from the West to the East. The resulting effects are large. If all migrants to the West had migrated to the East instead, the Communist Party would have gained an additional vote share of three percentage points. With 51 seats, the Communists would have gained the absolute majority in Parliament, so there would have been no change in government. We find a reverse effect if all migrants to the East had migrated to the West instead. This redirection of migration flows would have tripled the migrant population in the West and stripped the Communist Party of even more votes (five percentage points less), resulting in a landslide victory of the opposition.

The second part of the counterfactual analysis changes the level of migration flows: How successful would the Communist Party have been in the absence of migration to the West or East? We first examine the case with no migration to the West and unchanged migration to the East. The result suggests that westward migration has considerably harmed the Communist Party. The Communist Party would have gained two percentage points more votes (and only been one seat short of staying in power) if westward migrants had remained in Moldova. We find the opposite result for the case with no migration to the East and unchanged migration to the West. In this scenario, the Communist Party would have lost about two percentage points of votes. Hence, we can conclude that the Communist Party has likely benefited from emigration to the East.

Taken together, these counterfactual results suggest that the political consequences of emigration from Moldova are large and have considerably contributed to ending Communist rule in July of 2009. It is important to emphasize that we do not consider general equilibrium effects such as the effect of emigration on the political system. It is possible, for example, that the political platform of the Communist Party (or other political parties) may have been endogenous and responded to migration-induced changes in the electoral preferences of the median voter. To the extent that the Communist Party has made its political platform more liberal in response to changes in electoral preferences, our partial equilibrium analysis is therefore likely to underestimate the overall political effects of emigration to the West.

\section{What explains political spillovers of emigration?}

So far our analysis has established a close relationship between migration and voting patterns. Evidence from a variety of empirical specifications suggests that this relationship is causal or at least contains a large causal component. Westward migration clearly reduces electoral support for the 
Communist Party. The opposite is true for eastward migration, but the effect is less robust and less persistent. In this section, we collect suggestive evidence that the documented destination-specific political spillovers are indeed the result of transfers of information and norms from abroad. At the same time, we rule out three alternative explanations of the relationship between westward migration and political preferences: strategic voting, monetary remittances, and return migration.

\subsection{Transfer of information and norms}

To assess the role of information and norm transfers, we first examine whether there is effect heterogeneity that is consistent with this transmission channel. We then supplement this communitylevel evidence with an analysis of individual-level data on political preferences from a public opinion poll.

If political spillovers from abroad work through the transfer of information and norms, they should be strongest in areas where information asymmetries are large. For example, one would expect the spillover effects of westward migration to be more pronounced in rural areas, since these are typically less exposed to external influences and have less access to media. This is confirmed in column 1 of Table 8, in which we drop all 45 urban localities and find the coefficient of westward migration to increase to -0.73 . More importantly, we expect the transfer of information and norms from the West to be most relevant in communities with an older population, in which a higher share of voters grew up in Soviet times and was exposed to Soviet propaganda. In a similar vein, we expected larger effects in communities with a lower average level of education. We therefore split our sample at the median of the share of the population that was older than 21 years when the Soviet Union collapsed in 1991 and at the median of the share of the population with higher education. As columns 2-5 of Table 8 show, the effect of westward migration on Communist votes is indeed larger in communities that are older and less educated.

Another way to detect suggestive effect heterogeneity is to focus on the curvature of the observed relationship between migration and voting patterns. We expect a decreasing marginal effect of emigration on Communist votes, because information transmission should have decreasing returns. As more and more migrants leave a community for a given destination, an additional migrant should be less likely to transfer new information and norms from that destination. We test this prediction in column 6 of Table 8 by adding squared terms of the prevalence of westward and eastward migration to our baseline specification. For both westward and eastward migration, the squared terms are significant and have signs that are opposite of those of the linear terms, in line with our expectations. 
Finally, we investigate whether there is evidence of impact heterogeneity within the West. If political spillovers really operate through the transfer of information and norms, they should rise with the level of democracy at the destination, even within the West. There is relatively little variation across Western countries in the Polity IV score which we use to define Western and Eastern destinations (see Table 1). The Economist Intelligence Unit, however, provides an index of democracy ${ }^{31}$ that allows distinguishing between "full" and "flawed" democracies within the West. Flawed democracies in the West include Italy, Romania, Israel, Cyprus, Bulgaria and Poland. As column 7 of Table 8 shows, the effect of westward migration is much more pronounced for full democracies than for flawed democracies. A one-percentage point increase in the prevalence of emigration to full democracies in the West reduces the share of Communist votes by more than 1.3 percentage points. The equivalent marginal effect for emigration to a flawed Western democracy is only -0.33 and not precisely estimated. Hence, even within the West, our evidence is consistent with the idea that migrants diffuse democratic information and norms from abroad.

These heterogeneous effects are also important because they address potential concerns regarding the selection of migrants. As Table A5 in the appendix shows, Moldovan migrants to the West tend to be more educated, older and more female than migrants to the East. However, there are hardly any differences in the characteristics of migrants within the West. The distribution of skills and age groups is essentially the same for migrants to full Western democracies and migrants to flawed Western democracies. The only observable difference is that the share of women is higher among migrants to flawed democracies, which is due to the fact that Italy is a particularly popular destination for women. In addition, the distribution of Moldovan migrants across sectors and occupations is very similar within Western European destinations (Biroul Naţional de Statistică, 2009). Differences in migrant characteristics are therefore unlikely to explain the observed heterogeneous effects within the West (as is also suggested by our robustness check in Appendix 2).

As a more direct test for the transfer of information and norms from abroad, we draw on the Moldovan Political Barometer, a public opinion poll on socio-political issues that has been conducted biannually since 2001. ${ }^{32}$ Every wave interviews a random sample of about 1,000 individuals and is representative of the adult population at the national level. The set of questions asked changes considerably from wave to wave, but four politics-related questions have been

\footnotetext{
31 The Economist Intelligence Unit's democracy index is based on five categories: electoral process and pluralism; civil liberties; the functioning of government; political participation; and political culture. See Kekic (2006), for further details.

32 See Aghion et al. (2010) for a discussion and analysis of political preferences in transition countries.
} 
repeatedly asked over time. The four binary outcomes are: whether an individual (i) is satisfied with life in general, (ii) has trust in the government, (iii) has trust in local media, and (iv) would like the state to play an increased role to improve socio-economic conditions. In addition, we also examine an individual's intention to vote for the Communist Party should there be elections next Sunday.

To exploit the time dimension in the data, we pool all available waves conducted before the government changed in July 2009 that contain information on the location of the interview. This leaves us with eight waves, the first one being from April 2002 and the last one from March 2009. These years span almost the entire period during which the Communist Party was back in power. The resulting sample includes 8,350 individuals from 321 different communities in Moldova. We estimate an individual's views with a linear probability model controlling for her sex, age, education, and ethnicity as well as the same set of community-level variables (including district-level fixed effects) as in the baseline specification. To capture the evolution of views over time, we introduce an interaction term between westward/eastward migration and the year in which the interview took place. If migration really induces the transfer of information and norms, its effect should become increasingly visible over time.

Table 9 shows that individuals who live in communities with high levels of westward migration significantly change their views over the years. They are increasingly less satisfied with their lives, put less trust in the government and local media, and are more skeptical of state intervention. These findings are consistent with the argument that the transfer of information and norms changes the reference point of individuals and ultimately affects their political preferences. We also reproduce our main results and show that these individuals become increasingly less likely to vote for the Communist Party. Importantly, we observe no preference changes for individuals who live in communities with high levels of eastward migration, possibly because the news and views transmitted by eastward migrants are likely to contain little informational value. Indeed, due to the joint Soviet legacy and easy access to Russian media, Moldovans are arguably well-informed about the situation in Russia.

The results from the political barometer are also important because they are based on a representative sample of the total adult population, not on a sample of active voters. ${ }^{33}$ This difference is important because it suggests that the observed relationship between westward

${ }^{33}$ Note that we only observe the party choice for the sub-sample of individuals who stated that they would vote should there be elections next Sunday. All other outcomes (columns 2-6 of Table 9), however, are based on the total and representative sample. 
migration and voting patterns works through a change in electoral preferences and not through a change in the composition of active voters (e.g., through changes in the incentives of individuals with given electoral preferences to cast their vote). This conclusion can also be drawn from column 6 of Table 9 showing that individuals from communities with high levels of westward migration do not change their propensity to vote (should there be elections next Sunday) over the years. We further investigate the relationship between voter turnout and migration patterns at the community level. Column 1 of Table 10 regresses the voter turnout in the parliamentary elections of July 2009 on the prevalence of westward and eastward migration using the same set of control variables as our baseline specification. Both westward and eastward migration are associated with a significant reduction in voter turnout. The negative association reflects the absence of migrants from the electorate as migrants are typically not officially registered and therefore remain on voter lists. Column 2 uses our baseline specification and shows that our main results are stable if we control for voter turnout in the election of July 2009. Hence, changes in the propensity to vote among those who stay behind are unlikely to explain the observed destination-specific political spillovers.

\subsection{Strategic voting}

Political spillovers could also be the result of strategic voting. For example, voters with a migrant abroad may change their voting behavior to strategically support a party that is more likely to protect their migrant relatives abroad and secure the flow of remittances. Communities with migrants in the West may vote for the Alliance of European Integration because these parties are more likely to seek integration with Western Europe, possibly easing visa requirements and lowering the costs of sending remittances. By contrast, communities with migrants in the East may increase their support of the Communist Party to secure good relations between Moldova and Russia.

One way to test for strategic voting is to assess the curvature of the relationship between migration and voting patterns. The desire to protect migrants is likely to increase at least proportionally with emigration and the resulting dependency on remittances flows. However, as shown above (column 6 of Table 8), the magnitude of the marginal effect of emigration on Communist votes decreases with the level of emigration. In addition, the results from the Moldovan Political Barometer indicate that westward migration is also associated with changes in political, not only electoral, preferences (Table 9). Our previous results on differential effects within the West also provide strong evidence against strategic voting. In case of strategic voting, communities with migrants in full Western democracies should have similar electoral preferences as communities with migrants in flawed Western 
democracies. However, the former type of communities votes much less for the Communist Party than the latter type (column 7 of Table 8).

\subsection{Monetary remittances}

Monetary remittances represent another potential transmission channel of the political spillovers of emigration. Remittances can affect political preferences because they increase the disposable income of recipient households and also change income inequality within communities. For example, if remittances increase income inequality, it is reasonable to expect a higher vote share for the Communist Party, which favors redistributive policies.

To explain our main result, an increase in remittances from the East should increase support for the Communist Party, while remittances from the West should decrease support for the Communist Party. First, with respect to individual households, we cannot think of a plausible reason why remittances should have such a non-monotonic relationship with Communist votes. A dollar received from the West should have a similar income effect on electoral preferences as a dollar received from the East. Of course, there may be differences in consumption patterns and endowment levels between households with a migrant in the East of West, but these cannot explain why remittance from the West should have the opposite income effect than remittances from the East. Second, with respect to income inequality and wealth distribution within communities, the Communist Party should actually gain, not lose, votes in communities with high levels of westward migration. This is because Moldovan migrants in Western Europe remit on average about 50 percent more money than migrants in Russia (Luecke et al., 2007). Moreover, migrating to the West is costly, mainly due to visa restrictions, and was therefore more widespread among initially richer households. ${ }^{34}$ As a result, remittances from the West should have made relatively rich households richer, thus increasing income inequality and the demand for redistribution by the majority of voters (without a migrant abroad). The remittances-induced change in a community's income distribution should then make the Communist Party more popular - which is exactly the opposite of what political spillovers of westward migration would predict. In sum, remittances effects related to income levels and income inequality are unlikely to account for the destination-specific political effects that we observe. This conclusion is also suggested by our previous result on heterogeneous effects within the West. As migrant characteristics are relatively similar across Western destinations,

\footnotetext{
34 By contrast, eastward migration is cheap and accessible to poorer households as would-be migrants can relocate without a visa and only need to board a train to Russia (Luecke et al., 2007).
} 
differences in remittances patterns should not account for the stronger political spillovers from emigration to full Western democracies.

Remittances may, however, also have an indirect effect on electoral preferences through their effect on the local economy. It is possible that remittances from westward migrants have different local multiplier effects than remittances from eastward migrants and hence affect voting behavior in a different way. For instance, poorer households with a migrant in the East may primarily use remittances for subsistence needs. Richer households with a migrant in the West may spend part of the remittances on renovating or building a house, thereby creating more demand for local labor, or in some other conspicuous way. However, there is little evidence that households with westward migrants have different spending patterns than those with eastward migrants (Luecke et al., 2007).

Nevertheless, we address this concern by adding various proxies for local economic conditions to the

set of control variables. Specifically, we also control for night-time light intensity, per-capita tax revenues, the unemployment rate, and the per-capita number of shops. All variables are measured at the community level at the time of the parliamentary election of July 2009 (socio-economic statistics at the community level are available from 2006 onwards from the Moldovan Ministry of Economy and Trade). As shown in column 3 of Table 10, the inclusion of local economic indicators has no effect on the coefficients of westward and eastward migration. The same is true if we use the change in these economic variables from 2006 to 2009 instead of the 2009 levels. It hence seems unlikely that political spillovers from abroad work through the effect of remittances on the local economy.

\subsection{Return migration}

We finally consider return migration as a potential transmission channel. Indeed, the observed relationship between migration and voting patterns may not be due to migration-induced spillovers on those who stay behind, but to the return of former migrants to the electorate. To address this possibility, we commissioned two questions in an exit poll that was conducted in the parliamentary election of November 2010. Individuals were asked whether they themselves had ever lived abroad for at least three months since 1991 and if so in which destination, and whether family members had ever lived abroad and if so in which destination. We are thus able to distinguish between return migrants and non-migrants in the electorate.

The exit poll was conducted with 7,344 individuals in 71 communities. Respondents were approached just after they had cast their vote and asked about their sex, age, education, and ethnicity in addition to the two questions on personal and family migration experience. They were then given 
the questionnaire to tick the party they had voted for in a cabin similar to a polling booth and finally dropped the questionnaire in a box. The results should therefore not be manipulated or biased because of revealed electoral preferences. Because of time constraints, the exit poll only distinguished between destinations in the European Union, the Commonwealth of Independent States (an association of former Soviet republics including Russia), and the rest of the World. We classify the European Union as a Western destination and the two remaining regions as Eastern destinations.

We estimate an individual's decision to vote for the Communist Party using a linear probability model. We expect personal migration experience, but also indirect exposure to the West or East through family members abroad to be significantly associated with electoral preferences. Table 11 summarizes the results. Column 1 controls for an individual's sex, age, education, and ethnicity. Column 2 adds community fixed effects to capture unobserved heterogeneity between communities.

Individuals who have returned from the West are substantially less likely to vote for the Communist Party than individuals who have not been abroad. Having been to the West reduces the likelihood to vote for the Communist Party by seven percentage points. Having been to the East, however, is not significantly related to electoral behavior. The findings are almost identical for individuals with a family member abroad. Individuals with a family member in the West are eight percentage points less likely to give their vote to the Communist Party. The magnitude of the effect is large and comparable to the effect of having higher education. We find no significant association between having a family member in the East and voting for the Communist Party. ${ }^{35}$

The exit poll can also be used to look at the relationship between a community's migration prevalence and Communist votes for the sub-samples of (i) individuals with a family member in the West, (ii) individuals with a family member in the East, and (iii) non-migrant individuals with no family member abroad. If political spillovers from the West indeed operate through the transfer of information and norms, community-level exposure to the West should be less informative for individuals with family in the West (as they would receive this information directly from their migrants) and more informative for individuals with family in the East or no family abroad. Indeed, the community prevalence of emigration to the West has no significant association with Communist votes for the former group (column 3), but a negative and significant association with the latter two groups (columns 4 and 5). While these results do not necessarily reflect a causal relationship, they provide suggestive evidence for political spillovers of westward migration on those who stay behind

35 Likewise, our community-level analysis does not find a significant association between eastward migration and Communist votes in the parliamentary election of November 2010 (column 5 of Table 4). 
in Moldova. Hence, the relationship between migration and voting patterns is unlikely to be solely the outcome of return migration.

\subsection{Anecdotal evidence from interviews}

To better understand the mechanisms at work, we also conducted a series of non-structured interviews with return migrants and political observers (e.g., think tanks) in Moldova in July 2010 as well as with Moldovan migrants currently living in Western Europe (in June 2011 and December 2013). We asked what kind of information on politics and institutions migrants share with their friends and family in Moldova and whether such information transfers mattered.

The overall insight from these interviews is that many migrants in the West perceived themselves as "teaching" their family and friends on how Western Europe "works". Many interviewees portrayed those left behind as politically indifferent and uninformed, in particular in poor rural areas (as confirmed by surveys, see Section 2.2 above). Several migrants stated that they made outright electoral recommendations to those they talk with back home. For example, one female migrant in Italy told us that before the 2009 elections, she intentionally called up all of her family members and neighbors telling them not to be deceived by electoral gifts from Communist campaigners such as vodka or sacks of potatoes.

Corruption was one of the main political issues mentioned by the interviewees. Migrants told us that living in Western Europe had made them less likely to tolerate corruption and that they had encouraged their peers in Moldova not to pay bribes and to support parties with an anti-corruption agenda instead. We could not uncover evidence for strategic voting. No interviewee alluded to the fact that visa access or temporary work permits played a role for their political preferences or vote recommendations. However, several migrants told us that they communicated a broad "vision of Europe" and of modern societies, emphasizing positive characteristics such as economic prosperity, entrepreneurship and the free movement of people (due to the Schengen area). In sum, the qualitative interviews confirmed that information transmission may play an important role for voting decisions in localities with an uninformed electorate.

\section{Conclusion}

The fact that knowledge diffuses locally rather than globally (Jaffe, Trajtenberg and Henderson, 1993) has been seen as evidence that an important part of knowledge is tacit. This was recognized by sociologists and economists well before the diffusion of knowledge could be tracked through patent 
citations. For example, Polanyi (1966) or Arrow (1969) suggested that knowledge diffusion requires direct forms of human interaction. Hence, one would expect the international diffusion of knowledge to be affected by the pattern of international migration; and indeed, recent research has confirmed this conjecture (Kerr, 2008). The circulation of knowledge and ideas is not restricted to the technological realm. Rather, social norms and political preferences also diffuse through direct human interactions and their diffusion across borders is magnified by the cross-border movement of people. Such transfers of ideas and values have been termed "social remittances" when they occur from the destination to the origin country of migrants (Levitt, 1998). Political remittances have the potential to have a significant effect on the evolution of political preferences and change the economic and political trajectory of nations; in Rodrik's (2014) words, they have a strong emulation potential, especially in a globalized context with democratized access to communication and travel.

This paper uses individual survey and administrative data from Moldova, a former Soviet Republic, to investigate the effect of labor migration on political outcomes at home. In contrast to previous literature, we focus on political behavior (as election results are our main outcome of interest) and rely on differential (destination-specific) effects for identification. This is possible thanks to the fact that Moldovan emigration is polarized between two destinations characterized by very different democracy levels - the European Union and Russia - and to the quasi-experimental context in which the episode of mass emigration we analyze took place. The main challenge for identification is that migrants' destination choice, in particular the choice made by the first migrants (who then form migrant networks generating chain migration) could have been driven by political preferences or by a confounder that drives both migration and voting patterns at the community level. Most of our empirical analysis is aimed at addressing this issue. Our results cannot be explained by individual selfselection of migrants on political grounds (i.e., the fact that migrants with stronger preferences for democracy opt for more democratic destinations). If anything, the exit effect should increase, not decrease, the share of Communist votes in communities with significant emigration to the West. To address political selection at the community level, we control for a large range of community characteristics, including pre-migration political preferences (as measured by elections results from the mid-1990s) and intensity of the economic crisis (as measured by changes in levels of night-time light intensity obtained from satellite data). We also control for district fixed effects and allow for the definition of a district to vary arbitrarily. Hence, to challenge a causal interpretation, a remaining confounder must (i) be time-varying, (ii) be much more strongly associated with migration patterns and electoral preferences than important control variables, (iii) affect electoral preferences several 
years after migration took place, (iv) not affect neighboring communities in a similar way, and (v) account for the opposing effects of westward and eastward migration. While we cannot rule out such a confounder, we consider its existence implausible.

Our results show a significant and robust negative effect of emigration to the West between 1998 and 2004 on the share of votes for the Communist Party in the Moldovan elections of 2009-10. Moreover, the effect is large in terms of sheer magnitude (suggesting spillover effects more than compensated for the exit effect) as well as in terms of eventual consequences. Indeed, counterfactual simulations based on conservative scenarios suggest that emigration to the West may have been decisive in bringing an end to the reign of the last ruling Communist Party in Europe, twenty years after the fall of the Berlin wall. Finally, our results are suggestive of a preferences transmission mechanism, as attested by the presence of democratic spillovers to members of households without any migrant in our exit poll or by the fact that the effect of emigration on electoral outcomes is stronger in older and less educated communities, where the potential for new information to make a difference is presumably greater. Adding credence to this interpretation, the results appear to be driven by emigration to the sub-set of European countries with the highest democratic standards.

This paper, therefore, suggests that exit and voice can be complementary in bringing political change and jointly contribute to the global diffusion of democracy. Obviously, there have been many instances in recent history where emigration to Western democracies did not bring any democratic dividend to the home countries. Arguably, decades of Cuban immigration to the U.S. or of Northern-African immigration to Western Europe did little to promote democracy in Cuba or Algeria. The circumstances that explain whether a positive, neutral or negative outcome is obtained are unclear. They may have to do with the extent to which migrants can retain close ties and freely communicate with their home communities, as suggested in this paper, but also with the cultural distance between home and host countries, the degree of economic and social integration of immigrants in the host societies, or with the circumstances (revolution, economic crisis, ethnic conflict) that led to emigration in the first place. 


\section{Appendix}

\section{Appendix 1: Determinants of migration to the East and West}

This appendix analyzes the determinants of migration patterns at the community level using exactly the same set of explanatory variables as in our baseline regression in the main analysis (column 3 of Table 3). Table A1 below summarizes the results. The dependent variables are the overall prevalence of emigration (column 1), the share of westward migrants among all migrants (column 2), the prevalence of westward migration (column 3), and the prevalence of eastward migration (column 4).

A first important result is that pre-migration electoral preferences are not systematically associated with the size and direction of migrant flows. In particular, more liberal communities do not send more migrants to the West and more Communist communities do not send more migrants to the East. Conditional on observable community characteristics, there is little evidence for political selfselection of migrants at the community level.

Second, we find that adverse economic shocks pushed many Moldovans abroad, as is widely acknowledged in the literature. A reduction in night-time light intensity between 1992 and 1999 is associated with a significant increase in the prevalence of emigration. Importantly, however, adverse economic shocks cannot explain whether migrants left Moldova for the West or the East. Changes in night-time light intensity are not significantly related with the share of westward migrants among all migrants. This result is in line with the idea that, due to the role of migrant networks, it should primarily be the destination choice of the first migrants that affects that of subsequent migrants.

Third, we can confirm that the drivers of the destination choice of the first migrants are crucial determinants of migration patterns in 2004. Russian and Gagauz minorities facilitate migration flows to the East, while a high share of ethnic Moldovans, the reference category, is positively associated with migration flows to the West. In addition, communities that are closer to a Moldovan-Romanian border crossing see significantly more migration to the West. The marginal effect is large: A 35 kilometer decrease in distance is associated with a one-percentage point increase of a community's population in the West (even after controlling for district-fixed effects that already pick up large parts

of the border effects). Hence, small differences in pre-migration community characteristics have the potential to bring about large differences in migration patterns.

We also find that westward migration is more prevalent in larger communities and in communities with lower dependency ratios and a more educated population. These findings reflect that westward 
migration is more costly to finance than eastward migration and therefore more accessible to betteroff individuals who live in such communities (Luecke et al., 2007).

\section{Appendix 2: Robustness checks}

We perform a number of checks to assess the robustness of the baseline coefficients of westward and eastward migration. Table A4 below summarizes the results. Column 1 adds 5th-order polynomials of all control variables including pre-migration election results. In case the linear approximation used in the baseline specification is not valid, important confounding variables may still cause biased estimates of the coefficients of interest. 5th-order polynomials of the control variables would account for potential non-linearities in the relationship between community characteristics before migration took off and the evolution of migration and voting patterns thereafter. However, including the polynomials does not significantly change our coefficients of interest.

Column 2 includes the share of Communist votes in the parliamentary election of 2001, the year in which the Communist Party returned to power, as an additional regressor. Hence, we only analyze the change in electoral preferences for the period 2001-2009, during which the Communist Party had a firm grip on power in Moldova. Again, the coefficients of interest are not affected.

Column 3 controls for the demographic composition of migrant flows in terms of age, sex and education. In principle, the absence of certain types of individuals alone may already affect electoral preferences irrespective of the destination of migrants, e.g. through a change in gender roles in communities with a high female migration prevalence. To attribute the political effects of emigration to political spillovers from abroad, they should be unrelated to different pre-departure characteristics of migrants to the West and East. This is a valid concern for the case of Moldova because westward and eastward migrants differ somewhat in their demographic characteristics. Westward migrants are relatively more educated and female than eastward migrants (compare Table A5). However, our results are fully robust to the inclusion of the demographic characteristics of the migrants. If anything, the coefficient of westward migration becomes larger as the demographic characteristics partially capture migrants' electoral preferences and thus weaken the impact of the exit effect on the coefficient.

Next, we define the West without Italy, the most important destination of Moldovan migrants in Western Europe, and not necessarily an ideal-type democracy. In line with our finding that our results are mostly driven by emigration to the most advanced democracies, the effect of westward 
migration becomes even more pronounced (column 4). We also consider an alternative definition of the West based on the rule-of-law index from the World Bank Governance Indicators 2004. The ranking of destination countries relative to Moldova, however, is largely the same and our results do not change (column 5).

Finally, we assess the robustness of our model to using different econometric specifications. So far, we have relied on a specification with lagged outcomes as regressors rather than using first differences. We have done so for two reasons. First, the structure of our dataset is not a classic panel. The dependent variable is measured at different points in time than the explanatory variables. Taking differences would therefore require taking differences over different periods. Additionally, some explanatory variables are not observed at different points in time, which would not allow us to take differences. Second, first differencing would imply taking the differences between Communist votes in 1998 and 2009. Controlling for different dimensions of pre-migration electoral preferences in form of the vote shares of other parties would not be possible. At the same time, however, first differencing avoids potential endogeneity problems that may arise from the use of lagged outcomes as regressors in parametric models (Angrist and Pischke, 2008). In column 6, we therefore present the results of a first-difference specification. The coefficient of westward migration remains unaffected, but the coefficient of eastward migration ceases to be significant at usual significance levels.

In another specification we use the overall migration prevalence and the share of westward migrants among all migrants instead of the prevalence of emigration to the West and East (column 7). The coefficient of overall migration prevalence is close to zero and insignificant while the coefficient of the share of westward migrants is negative and highly significant, which is in line with the previous results.

Finally, we follow Spilimbergo (2009) and use a continuous measure of the level of democracy abroad instead of splitting migrants' destinations into Western and Eastern countries (column 8). The level of democracy abroad is defined as the weighted average of democracy scores in destination countries, where a country's weight is given by the share of migrants in that country among all migrants from the same community. An interaction term between overall migration prevalence and the level of democracy abroad then measures the degree of exposure to democracy abroad. The interaction term is negative and highly significant. Hence, the magnitude of the marginal effect of emigration on Communist votes increases with the level of democracy abroad. 


\section{References}

Abdih, Y., Chami, R., Dagher, J. and P. Montiel (2012). Remittances and Institutions: Are Remittances a Curse?, World Development, 40(4), 657-666.

Acemoglu, D., D. Cantoni, S. Johnson, and J. Robinson (2011). The Consequences of Radical Reform: The French Revolution, American Economic Review, 101(7), 3286-3307.

Acemoglu, D., S. Johnson, and J. A. Robinson (2001). The Colonial Origins of Comparative Development: An Empirical Investigation, American Economic Review, 91(5), 1369-1401.

Acemoglu, D., S. Johnson, J. A. Robinson, and P. Yared (2008). Income and Democracy, American Economic Review, 98(3), 808-842.

Aghion, P., Y. Algan, P. Cahuc, and A. Shleifer (2010). Regulation and Distrust, Quarterly Journal of Economics, 125(3), 1015-1049.

Agrawal, A.K, D. Kapur, J. McHale and A. Oettl (2011). Brain Drain or Brain Bank? The Impact of Skilled Emigration on Poor Country Innovation, Journal of Urban Economics, 69(1), 43-55.

Alesina, A., and N. Fuchs-Schuendeln (2007). Good-Bye Lenin (or Not?): The Effect of Communism on People's Preferences, American Economic Review, 97(4), 1507-1528.

Angrist, J.D., and J. Pischke (2008). Mostly Harmless Econometrics: An Empiricist's Companion, Princeton, NJ: Princeton University Press.

Arambaşa, M.N. (2009). Bedeutung der grenzüberschreitenden Praktiken im moldauischrumänischen Grenzraum vor und nach dem EU-Beitritt Rumäniens. In: Heller, W., and M. N. Arambaşa (eds.), Am östlichen Rand der Europäischen Union. Geopolitische, ethnische und nationale sowie ökonomische und soziale Probleme und ibre Folgen für die Grenaraumbevölkerung, Potsdam: Universitätsverlag Potsdam, 137-160.

Arrow, K. (1969). Classificatory Notes on the Production and Transmission of Technological Knowledge, American Economic Review, 59(2), 29-35.

Bandiera, O., I. Rasul and M. Viarengo (2013). The Making of Modern America: Migratory Flows in the Age of Mass Migration, Journal of Development Economics, 102, 23-47.

Barr, A., and D. Serra (2010). Corruption and Culture: An Experimental Analysis, Journal of Public Economics, 94, 862-869.

Batista, A., and P. Vicente (2011). Do Migrants Improve Governance at Home? Evidence from a Voting Experiment, World Bank Economic Review, 25(1), 77-104.

Beine, M., F. Docquier, and M. Schiff (2013). International Migration, Transfer of Norms and Home Country Fertility, Canadian Journal of Economics, 46(4), 1406-1430.

Bertoli, S., and F. Marchetta (forthcoming). Bringing It All Back Home: Return Migration and Fertility Choices, World Development.

Berry, J. W. (1997). Immigration, Acculturation, and Adaptation, International Journal of Applied Psychology, 46(1), 5-34.

Biroul Național de Statistică (2009). Migrația Forţei de Muncă. Chisinau.

Borjas, G., and K. Doran, (2012). The Collapse of the Soviet Union and the Productivity of American Mathematicians, Quarterly Journal of Economics, 127(3), 1143-1203.

Braga, M. (2007). Dreaming Another Life. The Role of Foreign Media in Migration Decisions. Evidence from Albania, Mimeo, Bocconi University.

Cain, B., R. Kiewiet, and C. Uhlaner (1991). The Acquisition of Partisanship by Latinos and Asian Americans, American Journal of Political Science, 35(2), 390-422. 
Cameron, L., N. Erkal, L. Gangadharan, and M. Zhang (2012). Cultural Integration: Experimental Evidence of Changes in Immigrants' Preferences, IZA Discussion Paper 6467.

Careja, R., and P. Emmenegger (2012). Making Democratic Citizens: The Effects of Migration Experience on Political Attitudes in Central and Eastern Europe, Comparative Political Studies, 45(7), 875-902.

Chauvet, L., and M. Mercier, (2013). Migration and Elections in Mali. Does Migration Promote Democratization in Africa?, Mimeo, Paris School of Economics.

Clingingsmith, D., A. I. Khwaja, and M. Kremer (2009). Estimating the Impact of the Hajj: Religion and Tolerance in Islam's Global Gathering, Quarterly Journal of Economics, 124(3), 1133-1170.

Colomer, J.M. (2000). Exit, Voice, and Hostility in Cuba, International Migration Review, 34(2), 423-442.

Combes, P.P., and H.G. Overman (2004). The Spatial Distribution of Economic Activities in the European Union. In: Henderson, J.V., and J.F. Thisse (eds.): Handbook of Regional and Urban Economics, vol. 4. Elsevier North-Holland.

Crowther, W.E. (2011). Second Decade, Second Chance? Parliament, Politics and Democratic Aspirations in Russia, Ukraine and Moldova, Journal of Legislative Studies, 17(2), 147-171.

DellaVigna, S. and M. Gentzkow, (2010). Persuasion: Empirical Evidence, Annual Review of Economics, 2(1), 643-669.

Docquier, F., and H. Rapoport (2012). Globalization, Brain Drain, and Development, Journal of Economic Literature, 50(3), 681-730.

Docquier, F., E. Lodigiani, H. Rapoport, and M. Schiff (2011). Emigration and Democracy, World Bank Policy Research Working Paper No. 5557

Enikolopov, R., M. Petrova, and E. Zhuravskaya (2011). Media and Political Persuasion: Evidence from Russia, American Economic Review, 107(2), 3253-3285.

European Comission (2012). Implementation of the European Neighbourhood Policy in the Republic of Moldova. Progress in 2011 and Recommendations for Action. http://ec.europa.eu/world/enp/docs/2012_enp_pack/progress_report_moldova_en.pdf

Fargues, P. (2007). The Demographic Benefit of International Migration: a Hypothesis and its Application to Middle Eastern and North African Countries. In: Ozden, C., and M. Schiff (eds.), International Migration, Economic Development and Policy, World Bank: Washington, DC.

Ferguson, J. (2003). Migration in the Caribbean: Haiti, the Dominican Republic and Beyond, Minority Rights Group International.

Fidrmuc, J., and O. Doyle (2004). Voice of the Diaspora: An Analysis of Migrant Voting Behavior, CEPR Discussion Paper No. 4619.

Görlich, D., and C. Trebesch (2008). Seasonal Migration and Networks. Evidence on Moldova's Labour Exodus, Review of World Economics (Weltwirtschaftliches Archiv), 144(1), 107-133.

Gould, D.M. (1994). Immigrant Links to the Home Country: Empirical Implication for US Bilateral Trade Flows, Review of Economics and Statistics, 76(2), 302-316.

Gugushvili, A. (2011). Democratic Discontent and Emigration: Do Political Attitudes Explain Emigration Intentions? Mimeo, European University Institute.

Hansen, L. O. (1988). The Political and Socio-economic Context of Legal and Illegal Mexican Migration to the U.S. (1942-1984), International Migration, 26(1), 95-107.

Henderson, V., A. Storeygard, and D. Weil (2012). Measuring Economic Growth from Outer Space, American Economic Review, 102(2), 994-1028. 
Hersh, J., and J. Voth (2011). Sweet Diversity: Colonial Goods and the Rise of European Living Standards After 1492, Universitat Pompeu Fabra Working Paper 1163.

Hirschman, A O. (1970). Exit, Voice, and Loyalty: Responses to Decline in Firms, Organizations, and States. Cambridge, MA: Harvard University Press.

Hirschman, A.O. (1993). Exit, Voice, and the Fate of the German Democratic Republic: An Essay in Conceptual History, World Politics, 45(2), 173-202.

Hoffman, B. (2005). Emigration and Regime Stability: Explaining the Persistence of Cuban Socialism, Journal of Communist Studies and Transition Politics, 21(4), 436-461.

Hornung, E. (2014). Immigration and the Diffusion of Technology: The Huguenot Diaspora in Prussia, American Economic Review, 104(1), 84-122.

IDIS Viitorul (2009). Report on the Assessment of Public Perception regarding the Process of European Integration and Implementation of EUMAP - Republic of Moldova, Institute for Development and Social Initiatives, Chisinau.

IJC (2009). An Assessment of the State of the Media in the Republic of Moldova. Independent Journalism Center. http:/ /www.ijc.md/eng/index.php?option=com_content\&task=view\&id=245.

Jaffe, A.B., M. Trajtenberg and R. Henderson (1993). Geographic Location of Knowledge Spillovers as Evidenced by Patent Citations, Quarterly Journal of Economics, 108(3), 577-98.

Javorcik, B.S., C. Ozden, M. Spatareanu, and I.C. Neagu (2011)?. Migrant Networks and Foreign Direct Investment, Journal of Development Economics, 94(2), 231-241.

Jensen, R., and E. Oster (2009). The Power of TV: Cable Television and Women's Status in India. Quarterly Journal of Economics, 124(3), 1057-1094.

Kekic, L. (2006). The Economist Intelligence Unit's Index of Democracy. The World in 2007. Economist Intelligence Unit.

Kerr, W.R. (2008). Ethnic Scientific Communities and International Technology Diffusion, Review of Economics and Statistics, 90(3), 518-537.

Kim, J., E. Elliott , and D.M. Wange (2003). A Spatial Analysis of County-Level Outcomes in US Presidential Elections: 1988-2000, Electoral Studies, 22(4), 741-761.

Krause, A. (2000). Трудовая миграция населения Молдо-вы: состояние и перспективы, Moldoscopie, 13, 87-103.

Kugler, M., and H. Rapoport (2007). International Labor and Capital Flows: Complements or Substitutes?, Economic Letters, 94(2), 155-162.

Levitt, P. (1998). Social Remittances: Migration-Driven Local-Level Forms of Cultural Diffusion, International Migration Review, 32(4), 926-948.

Luecke, M., T. Omar Mahmoud, and P. Pinger (2007). Patterns and Trends of Migration and Remittances in Moldova - The CBSAXA Survey 2006, International Organization for Migration (IOM), Chisinau.

Luecke, M., T. Omar Mahmoud, and A. Steinmayr (2009). Labour Migration and Remittances in Moldova: Is the Boom Over? - The IOM-CBSAXA Panel Household Survey 2006-2008, International Organization for Migration (IOM), Chisinau.

Luttmer, E.F.P. and M. Singhal. (2011). Culture, Context, and the Taste for Redistribution, American Economic Journal: Economic Policy, 3(1), 157-179.

Marandici, I. (2010). The Factors Leading to the Electoral Success, Consolidation and Decline of the Moldovan Communists' Party, Paper Presented at the Midwestern Political Science Association Meetings, April 2010. 
Marcu, S. (2009). The Geopolitics of the Eastern Border of the European Union: The Case of Romania-Moldova-Ukraine, Geopolitics, 14(3), 409-432,

McKenzie, D., and H. Rapoport (2010). Self-selection Patterns in Mexico-US Migration: The Role of Migration Networks, Review of Economics and Statistics, 92(4), 811-821.

Michalon, B. (2009). Mobilitätspraktiken und Strategien von Kleinhändlern im grenzüberschreitenden Verkehr an der rumänisch-moldawischen Grenze vor dem EU-Beitritt, In: Heller, W., and M. N. Arambaşa, Am östlichen Rand der Europäischen Union. Geopolitische, ethnische und nationale sowie ökonomische und soziale Probleme und ihre Folgen für die Grenzraumbevölkerung, Potsdam: Universitätsverlag Potsdam, 125-136.

Moşneaga, V. (2009). Moldovan Population in the Context of Current Migration Processes, In: Madveev, D., Selari, G., Bobkova, E., and B. Cseke, Moldova-Transdniestria: Working Together for a Prosperous Future, Cudrag Publishing House, 156-172.

Moşneaga, V., G. Mohammadifard, and L. Corbu-Drumea, (2006). The Population of the Republic of Moldova in the Context of International Migration, Materials of the International Scientific Conference "Intercultural Dialogue" in Chisinau, 9-10 November 2005.

Mungiu-Pippidi, A., and I. Munteanu. (2009). Moldova's “Twitter Revolution”, Journal of Democracy, 20(3), 136-142.

Munshi, K. (2003). Networks in the Modern Economy: Mexican Migrants in the U.S. Labor Market, Quarterly Journal of Economics, 118(2), 549-599

Nunn, N., and N. Qian (2011). The Potato's Contribution to Population and Urbanization: Evidence from a Historical Experiment, Quarterly Journal of Economics, 126(2), 593-650.

Open Society Foundations (2012). Mapping Digital Media: Moldova, Report of January 2012, http:/ /www.opensocietyfoundations.org/sites/default/files/mapping-digitalmedia-moldova20120301.pdf.

Open Source Center (2008). Media Survey Report: Moldova, http://info.publicintelligence.net/OSC-MoldovaMedia.pdf.

OSCE (1998). Republic of Moldova: Parliamentary Elections, 22 March 1998, Final Report of the OSCE/ODIHR Election Observation Mission.

OSCE (2001). Republic of Moldova: Parliamentary Elections, 25 February 2001, Final Report of the OSCE/ODIHR Election Observation Mission.

OSCE (2005). Republic of Moldova: Parliamentary Elections, 6 March 2005, Final Report of the OSCE/ODIHR Election Observation Mission.

OSCE (2009). Republic of Moldova: Early Parliamentary Elections, 29 July 2009, Final Report of the OSCE/ODIHR Election Observation Mission.

Pattie, C., D. Dorling, and R. Johnston (1997). The Electoral Geography of Recession: Local Economic Conditions, Public Perceptions and the Economic Vote in the 1992 British General Election, Transactions, 22(2), 147-161.

Pérez-Armendáriz, C., and D. Crow (2010). Do Migrants Remit Democracy? International Migration, Political Beliefs, and Behavior in Mexico, Comparative Political Studies, 43(1), 119-148.

Pfaff, S., and H. Kim (2003). Exit-Voice Dynamics in Collective Action: An Analysis of Emigration and Protest in the East German Revolution, American Journal of Sociology 109(2), 401-444.

Pfutze, T. (2012). Does Migration Promote Democratization? Evidence from the Mexican Transition, Journal of Comparative Economics, 40(2), 159-175.

Polanyi, M. (1966). The Tacit Dimension. New York: Doubleday. 
Quinlan, P. D. (2004). Back to the Future: An Overview of Moldova under Voronin, Demokratizatsiya: The Journal of Post-Soviet Democratization, 12(4), 485-504.

Radziwill, A., O. Scerbatchi, and C. Zaman (1999). Financial Crisis in Moldova - Causes and Consequences, CASE Network Studies and Analyses No. 192.

Rauch, J.E., and V. Trindade (2002). Ethnic Chinese Networks in International Trade, Review of Economics and Statistics, 84(1), 116-130.

Rodrik, D. (2014). When Ideas Trump Interests: Preferences, World Views, and Policy Innovations. Journal of Economic Perspectives, 28(1), 189-208.

Sandu, D., V. Grigoraș, G. Toth, A. Toth, A. Bleahu, C. Radu, C. Radu (2006). Living Abroad on a Temporary Basis. The Economic Migration of Romanians: 1990-2006, Bucharest: Open Society Foundation.

Shain, Y. (1999). Marketing the American Creed Abroad: Diasporas in the U.S. and Their Homelands. Cambridge, UK/New York: Cambridge University Press.

Skoglund, P. et al. (2012). Origins and Genetic Legacy of Neolithic Farmers and Hunter-Gatherers in Europe, Science, 336(6080), 466-469.

Spilimbergo, A. (2009). Democracy and Foreign Education, American Economic Review, 99(1), 528-543.

Toka, G. and M. Popescu (2008). Inequalities of Political Influence in New Democracies, International Journal of Sociology, 37(4), 67-93.

Waldinger, F. (2010). Quality Matters: The Expulsion of Professors and the Consequences for PhD Student Outcomes in Nazi Germany, Journal of Political Economy, 118(4), 787-831.

Waldinger, F. (2012). Peer Effects in Science: Evidence from the Dismissal of Scientists in Nazi Germany, Review of Economic Studies, 79(2), 838-861.

White, S., N. Nevitte, A. Blais, E. Gidengil, and P. Fournier, (2008). The Political Resocialization of Immigrants: Resistance or Lifelong Learning?, Political Research Quarterly, 61(2), 268-281.

World Bank (2012). Doing Business in a More Transparent World, Washington D.C.: World Bank Publishers. 


\section{Tables (including appendix tables)}

Table 1: Number of Moldovan emigrants to the West and East in 2004

\begin{tabular}{|c|c|c|c|c|c|c|c|}
\hline \multicolumn{4}{|c|}{ Emigrants to the West } & \multicolumn{4}{|c|}{ Emigrants to the East } \\
\hline Country & $\begin{array}{c}\text { Democracy } \\
\text { score }\end{array}$ & $\begin{array}{c}\text { Number of } \\
\text { emigrants }\end{array}$ & $\begin{array}{l}\text { Share of } \\
\text { emigrants }\end{array}$ & Country & $\begin{array}{c}\text { Democracy } \\
\text { score }\end{array}$ & $\begin{array}{c}\text { Number of } \\
\text { emigrants }\end{array}$ & $\begin{array}{l}\text { Share of } \\
\text { emigrants }\end{array}$ \\
\hline Italy & 10 & 53,010 & $52.83 \%$ & Russia & 6 & 153,361 & $88.79 \%$ \\
\hline Romania & 9 & 10,515 & $10.48 \%$ & Ukraine & 6 & 8,582 & $4.97 \%$ \\
\hline Portugal & 10 & 9,467 & $9.43 \%$ & Turkey & 7 & 8,228 & $4.76 \%$ \\
\hline Greece & 10 & 5,584 & $5.56 \%$ & Belarus & -7 & 356 & $0.21 \%$ \\
\hline Spain & 10 & 3,868 & $3.85 \%$ & South Korea & 8 & 174 & $0.10 \%$ \\
\hline France & 9 & 3,504 & $3.49 \%$ & Serbia & 6 & 121 & $0.07 \%$ \\
\hline Israel & 10 & 2,634 & $2.62 \%$ & Kazakhstan & -6 & 119 & $0.07 \%$ \\
\hline Germany & 10 & 1,906 & $1.90 \%$ & Other countries & $\leq 8$ & 1,777 & $1.03 \%$ \\
\hline Czech Republic & 10 & 1,787 & $1.78 \%$ & & & & \\
\hline Great Britain & 10 & 1,399 & $1.39 \%$ & & & & \\
\hline Ireland & 10 & 1,235 & $1.23 \%$ & & & & \\
\hline United States & 10 & 1,184 & $1.18 \%$ & & & & \\
\hline Cyprus & 10 & 855 & $0.85 \%$ & & & & \\
\hline Bulgaria & 9 & 698 & $0.70 \%$ & & & & \\
\hline Belgium & 10 & 660 & $0.66 \%$ & & & & \\
\hline Austria & 10 & 505 & $0.50 \%$ & & & & \\
\hline Canada & 10 & 387 & $0.39 \%$ & & & & \\
\hline Poland & 10 & 234 & $0.23 \%$ & & & & \\
\hline Switzerland & 10 & 215 & $0.21 \%$ & & & & \\
\hline Netherlands & 10 & 142 & $0.14 \%$ & & & & \\
\hline $\begin{array}{l}\text { Other } \\
\text { countries }\end{array}$ & $\geq 9$ & 556 & $0.55 \%$ & & & & \\
\hline Total West & & 100,345 & $100.00 \%$ & Total East & & 172,718 & $100.00 \%$ \\
\hline
\end{tabular}

The table shows the distribution of Moldovan emigrants across destination countries based on Moldova's population census of 2004. Destination countries are classified as West if they have a higher level of democracy (as measured by the 2004 Polity IV score) than Moldova. Countries are classified as East if they have a lower or equal level of democracy than Moldova. Moldova's 2004 Polity IV score is 8. 
Table 2: Summary statistics of community-level variables

\begin{tabular}{|c|c|c|c|c|c|}
\hline Variable & Obs. & Mean & Std. dev & Min & Max \\
\hline Overall prevalence of emigration (\%) & 848 & 8.69 & 3.77 & 0 & 30.49 \\
\hline Prevalence of emigration to the West (\%) & 848 & 2.84 & 2.67 & 0 & 16.21 \\
\hline Prevalence of emigration to the East (\%) & 848 & 5.86 & 3.45 & 0 & 29.74 \\
\hline Share of westward migrants among all migrants (\%) & 847 & 32.67 & 23.22 & 0 & 94.62 \\
\hline Communist Party July 2009 (\%) & 848 & 46.75 & 19.77 & 4.70 & 97.97 \\
\hline Communist Party $2005(\%)$ & 848 & 51.49 & 13.58 & 10.78 & 91.97 \\
\hline Communist Party 2001 (\%) & 848 & 49.91 & 17.81 & 4.67 & 97.03 \\
\hline Communist Party 1998 (\%) & 848 & 29.51 & 19.83 & 1.51 & 94.50 \\
\hline Democratic Party $1998(\%)$ & 848 & 18.71 & 11.72 & 0.62 & 82.87 \\
\hline Democratic Convention $1998(\%)$ & 848 & 18.67 & 14.62 & 0 & 74.45 \\
\hline Party of Democratic Forces 1998 (\%) & 848 & 8.54 & 7.22 & 0 & 75.18 \\
\hline Voter turnout $1998(\%)$ & 848 & 79.62 & 9.67 & 41.19 & 100 \\
\hline Democratic Agrarian Party 1994 (\%) & 848 & 53.79 & 22.36 & 1.49 & 96.68 \\
\hline Socialist Party $1994(\%)$ & 848 & 12.04 & 20.43 & 0 & 96.36 \\
\hline Peasants and Intellectuals Bloc 1994 (\%) & 848 & 9.45 & 8.25 & 0 & 56.48 \\
\hline Alliance Pop. Christian Dem. Front 1994 (\%) & 848 & 6.98 & 6.35 & 0 & 56.81 \\
\hline Community size $0-1500$ & 848 & 0.28 & 0.45 & 0 & 1 \\
\hline Community size $1501-3000$ & 848 & 0.42 & 0.49 & 0 & 1 \\
\hline Community size $>3000$ & 848 & 0.30 & 0.46 & 0 & 1 \\
\hline District capital & 848 & 0.04 & 0.19 & 0 & 1 \\
\hline Distance to district capital $(\mathrm{km})$ & 848 & 14.74 & 8.76 & 0 & 87.31 \\
\hline Distance to Romanian border crossing $(\mathrm{km})$ & 848 & 54.99 & 29.07 & 1.52 & 151.24 \\
\hline Chisinau/Balti & 848 & 0.00 & 0.05 & 0 & 1 \\
\hline Population $0-14$ years (\%) & 848 & 21.18 & 3.20 & 10.62 & 34.60 \\
\hline Population $15-34$ years $(\%)$ & 848 & 30.04 & 3.78 & 18.62 & 41.23 \\
\hline Population 65 years and older (\%) & 848 & 12.36 & 4.71 & 2.92 & 29.71 \\
\hline Population with higher education (\%) & 848 & 15.72 & 6.06 & 4.03 & 47.45 \\
\hline Population with primary or no education (\%) & 848 & 53.78 & 10.65 & 11.32 & 85.79 \\
\hline Ratio high-skilled/low-skilled & 848 & 0.33 & 0.28 & 0.05 & 4.19 \\
\hline Ethnic Russians (\%) & 848 & 2.16 & 6.48 & 0 & 95.18 \\
\hline Ethnic Ukrainians (\%) & 848 & 8.41 & 19.39 & 0 & 93.21 \\
\hline Ethnic Gagauz (\%) & 848 & 3.02 & 14.61 & 0 & 97.88 \\
\hline Ethnic Bulgarians (\%) & 848 & 1.87 & 8.90 & 0 & 91.74 \\
\hline Ethnic fractionalization & 848 & 0.16 & 0.18 & 0.01 & 0.79 \\
\hline Change night-time light 1992-1999 & 848 & -4.82 & 3.27 & -22.41 & 0.87 \\
\hline
\end{tabular}

The table presents summary statistics for the main community-level variables used in our analysis. Data on migration patterns as well as demographic, ethnic and socio-economic composition of the population come from Moldova's population census of 2004 and are based on the total population including emigrants. All electoral variables are based on official results of parliamentary elections. The variable based on night-time light measures the difference between the average night-time light intensity on the territory of each community between 1992 and 1999. It is based on data from the Defense Meteorological Satellite Program's Operational Linescan System. 
Table 3: Migration patterns and results of the July 2009 parliamentary election

\begin{tabular}{|c|c|c|c|c|c|c|c|}
\hline & \multicolumn{3}{|c|}{$\begin{array}{l}\text { Share of votes for the } \\
\text { Communist Party }(\%)\end{array}$} & \multicolumn{4}{|c|}{$\begin{array}{c}\text { Share of votes for } \\
\text { opposition parties }(\%)\end{array}$} \\
\hline & $\begin{array}{c}\text { Basic } \\
\text { controls }\end{array}$ & $\begin{array}{l}\text { Plus pre- } \\
\text { migration } \\
\text { election } \\
\text { results }\end{array}$ & $\begin{array}{l}\text { Plus night- } \\
\text { time light } \\
\text { (full model) }\end{array}$ & $\begin{array}{c}\text { Liberal } \\
\text { Democratic } \\
\text { Party }\end{array}$ & $\begin{array}{l}\text { Liberal } \\
\text { Party }\end{array}$ & $\begin{array}{c}\text { Demo- } \\
\text { cratic } \\
\text { Party }\end{array}$ & $\begin{array}{c}\text { Party } \\
\text { Alliance } \\
\text { Our } \\
\text { Moldova }\end{array}$ \\
\hline & $(1)$ & $(2)$ & (3) & (4) & (5) & (6) & (7) \\
\hline $\begin{array}{l}\text { Prevalence of emigration } \\
\text { to the West }(\%)\end{array}$ & $\begin{array}{c}-0.70 * * * \\
(0.20)\end{array}$ & $\begin{array}{c}-0.63^{* * *} \\
(0.18)\end{array}$ & $\begin{array}{c}-0.63^{* * *} \\
(0.18)\end{array}$ & $\begin{array}{c}0.40 * * * \\
(0.13)\end{array}$ & $\begin{array}{c}0.24 * * \\
(0.11)\end{array}$ & $\begin{array}{c}0.08 \\
(0.12)\end{array}$ & $\begin{array}{l}-0.16 \\
(0.15)\end{array}$ \\
\hline $\begin{array}{l}\text { Prevalence of emigration } \\
\text { to the East }(\%)\end{array}$ & $\begin{array}{c}0.44^{* *} \\
(0.17)\end{array}$ & $\begin{array}{l}0.39 * * \\
(0.16)\end{array}$ & $\begin{array}{c}0.39 * * \\
(0.16)\end{array}$ & $\begin{array}{l}-0.07 \\
(0.09)\end{array}$ & $\begin{array}{c}-0.17 * * \\
(0.07)\end{array}$ & $\begin{array}{l}-0.07 \\
(0.08)\end{array}$ & $\begin{array}{l}-0.01 \\
(0.11)\end{array}$ \\
\hline Basic controls & yes & yes & yes & yes & yes & yes & yes \\
\hline $\begin{array}{l}\text { Pre-migration election } \\
\text { results }\end{array}$ & - & yes & yes & yes & yes & yes & yes \\
\hline Night-time light & - & - & yes & yes & yes & yes & yes \\
\hline District fixed effects & yes & yes & yes & yes & yes & yes & yes \\
\hline Number of observations & 848 & 848 & 848 & 848 & 848 & 848 & 848 \\
\hline $\mathrm{R}^{2}$ & 0.78 & 0.82 & 0.82 & 0.56 & 0.66 & 0.42 & 0.37 \\
\hline
\end{tabular}

The table reports OLS estimates for 848 Moldovan communities. The dependent variables are the vote shares of different parties in the July 2009 parliamentary election at the community level (in percent). Table A3 in the appendix shows the full regression results. Standard errors clustered at the district level in parentheses. *** denotes statistical significance at the 1 percent level, ** at the 5 percent level, and $*$ at the 10 percent level.

Table 4: Migration patterns and Communist votes over time, 2001-2010

\begin{tabular}{|c|c|c|c|c|c|c|c|c|}
\hline & \multicolumn{5}{|c|}{$\begin{array}{l}\text { Share of Communist votes } \\
\text { in parliamentary elections }(\%)\end{array}$} & \multicolumn{3}{|c|}{ Communist mayor (dummy) } \\
\hline & 2001 & 2005 & $\begin{array}{l}\text { April } \\
2009\end{array}$ & $\begin{array}{l}\text { July } \\
2009\end{array}$ & 2010 & 1999 & 2003 & 2007 \\
\hline & $(1)$ & $(2)$ & (3) & (4) & $(5)$ & $(6)$ & $(7)$ & $(8)$ \\
\hline $\begin{array}{l}\text { Prevalence of emigration } \\
\text { to the West }(\%)\end{array}$ & $\begin{array}{l}-0.30 \\
(0.30)\end{array}$ & $\begin{array}{l}-0.18 \\
(0.34)\end{array}$ & $\begin{array}{c}-0.40^{* *} \\
(0.20)\end{array}$ & $\begin{array}{c}-0.63^{* * *} \\
(0.18)\end{array}$ & $\begin{array}{c}-0.85^{* * *} \\
(0.17)\end{array}$ & $\begin{array}{l}-0.00 \\
(0.01)\end{array}$ & $\begin{array}{l}-0.00 \\
(0.01)\end{array}$ & $\begin{array}{c}-0.02 * * \\
(0.01)\end{array}$ \\
\hline $\begin{array}{l}\text { Prevalence of emigration } \\
\text { to the East }(\%)\end{array}$ & $\begin{array}{c}0.00 \\
(0.14)\end{array}$ & $\begin{array}{l}-0.13 \\
(0.16)\end{array}$ & $\begin{array}{l}0.27 * \\
(0.14)\end{array}$ & $\begin{array}{l}0.39 * * \\
(0.16)\end{array}$ & $\begin{array}{c}0.20 \\
(0.20)\end{array}$ & $\begin{array}{c}0.00 \\
(0.01)\end{array}$ & $\begin{array}{l}-0.00 \\
(0.01)\end{array}$ & $\begin{array}{c}0.00 \\
(0.01)\end{array}$ \\
\hline Full set of controls & yes & yes & yes & yes & yes & yes & yes & yes \\
\hline District fixed effects & yes & yes & yes & yes & yes & yes & yes & yes \\
\hline Number of observations & 848 & 848 & 848 & 848 & 848 & 822 & 848 & 848 \\
\hline $\mathrm{R}^{2}$ & 0.79 & 0.52 & 0.68 & 0.82 & 0.82 & 0.22 & 0.19 & 0.18 \\
\hline
\end{tabular}

The table reports OLS estimates for 848 Moldovan communities. The dependent variables are the vote shares of the Communist Party in the parliamentary elections between 2001 and 2010 at the community level (in percent) (columns 15) and a binary indicator whether a Communist mayor was elected in the municipal elections of 1999, 2003 , and 2007 (columns 6-8). Standard errors clustered at the district level in parentheses. $* * *$ denotes statistical significance at the 1 percent level, ** at the 5 percent level, and $*$ at the 10 percent level. 
Table 5: Migration patterns and Communist votes with fixed effects for geographical grid cells

\begin{tabular}{|c|c|c|c|c|}
\hline & \multicolumn{2}{|c|}{ 30x30km grid cells } & \multicolumn{2}{|c|}{$15 \times 15 \mathrm{~km}$ grid cells } \\
\hline & 1st iteration & $\begin{array}{c}\text { Average over } \\
100 \text { replications }\end{array}$ & 1st iteration & $\begin{array}{c}\text { Average over } \\
100 \text { replications }\end{array}$ \\
\hline & $(1)$ & $(2)$ & (3) & (4) \\
\hline $\begin{array}{l}\text { Prevalence of emigration } \\
\text { to the West }(\%)\end{array}$ & $\begin{array}{c}-0.56^{* * *} \\
(0.18)\end{array}$ & -0.53 & $\begin{array}{c}-0.61 * * * \\
(0.22)\end{array}$ & -0.50 \\
\hline $\begin{array}{l}\text { Prevalence of emigration } \\
\text { to the East }(\%)\end{array}$ & $\begin{array}{c}0.42^{* * *} \\
(0.14)\end{array}$ & 0.41 & $\begin{array}{c}0.37 * * * \\
(0.15)\end{array}$ & 0.29 \\
\hline Full set of controls & yes & yes & yes & yes \\
\hline Grid cell fixed effects & yes & yes & yes & yes \\
\hline Replications & & 100 & & 100 \\
\hline Avg. number of grid cells & & 52 & & 162 \\
\hline Number of observations & 848 & & 848 & \\
\hline $\mathrm{R}^{2}$ & 0.81 & & 0.85 & \\
\hline
\end{tabular}

The table reports OLS estimates for 848 Moldovan communities. The dependent variable is the vote share of the Communist Party in the July 2009 parliamentary election at the community level (in percent). The regressions include dummies for geographical grid cells of different sizes. Figure A2 in the appendix illustrate how the quadratic grid cells compare to the size of Moldovan districts. Columns 2 and 4 shift the grid in random directions and show average results after 100 iterations. Standard errors clustered at the district level in parentheses. $* * *$ denotes statistical significance at the 1 percent level, ${ }^{* *}$ at the 5 percent level, and $*$ at the 10 percent level.

Table 6: Migration patterns and Communist votes accounting for the exit of migrants from the electorate

\begin{tabular}{|c|c|c|c|}
\hline $\begin{array}{r}\text { Assumed electoral preferences of } \\
\text { emigrants to the West: }\end{array}$ & Same as community & Non-Communist & Communist \\
\hline \multirow{2}{*}{$\begin{array}{r}\text { Assumed electoral preferences of } \\
\text { emigrants to the East: }\end{array}$} & Same as community & Non-Communist & Communist \\
\hline & (1) & $(2)$ & (3) \\
\hline $\begin{array}{l}\text { Prevalence of emigration to the } \\
\text { West }(\%)\end{array}$ & $\begin{array}{c}-0.63^{* * *} \\
(0.18)\end{array}$ & $\begin{array}{c}-1.11 * * * \\
(0.15)\end{array}$ & $\begin{array}{l}0.28^{*} \\
(0.17)\end{array}$ \\
\hline $\begin{array}{l}\text { Prevalence of emigration to the } \\
\text { East }(\%)\end{array}$ & $\begin{array}{c}0.39 * * \\
(0.16)\end{array}$ & $\begin{array}{c}-0.48^{* *} \\
(0.19)\end{array}$ & $\begin{array}{c}0.99 * * * \\
(0.17)\end{array}$ \\
\hline Full set of controls & yes & yes & yes \\
\hline District fixed effects & yes & yes & yes \\
\hline Number of observations & 848 & 848 & 848 \\
\hline $\mathrm{R}^{2}$ & 0.82 & 0.81 & 0.82 \\
\hline
\end{tabular}

The table reports OLS estimates for 848 Moldovan communities The dependent variable is the hypothetical vote share of the Communist Party in the July 2009 parliamentary election at the community level (in percent), assuming that emigrants would not have left Moldova and remained part of their communities' electorate. We assume that migrants would have had the average voter turnout of their home communities. Standard errors clustered at the district level in parentheses. *** denotes statistical significance at the 1 percent level, ** at the 5 percent level, and * at the 10 percent level. 
Table 7: Counterfactual results of the July 2009 parliamentary election

\begin{tabular}{|c|c|c|c|c|}
\hline & \multicolumn{2}{|c|}{ Communist votes (\%) } & \multicolumn{2}{|c|}{$\begin{array}{l}\text { Communist seats } \\
\text { in Parliament }\end{array}$} \\
\hline & Level & $\begin{array}{l}\text { Change w.r.t. } \\
\text { observed result }\end{array}$ & Level & $\begin{array}{l}\text { Change w.r.t } \\
\text { observed result }\end{array}$ \\
\hline Observed result in July 2009 parliamentary elections & 45.3 & & 48 & \\
\hline \multicolumn{5}{|l|}{ 1) Same level of emigration, but to different destinations } \\
\hline a) Move migrants from West to East & 48.3 & +3.0 & 51 & +3 \\
\hline b) Move migrants from East to West & 40.4 & -4.9 & 43 & -5 \\
\hline \multicolumn{5}{|l|}{ 2) No emigration to the West or/and East } \\
\hline $\begin{array}{l}\text { a) No emigration to the West, same level of } \\
\text { emigration to the East }\end{array}$ & 47.2 & 1.8 & 50 & +2 \\
\hline $\begin{array}{l}\text { b) No emigration to the East, same level of } \\
\text { emigration to the West }\end{array}$ & 43.5 & -1.9 & 46 & -2 \\
\hline
\end{tabular}

The table reports counterfactual vote shares of the Communist Party and the resulting changes in the distribution of parliamentary seats for the July 2009 parliamentary election using different migration scenarios. With a total of 101 seats in Parliament, one percent of the votes correspond roughly to one seat in Parliament. An absolute majority of 51 seats is needed to form the government. The counterfactual analysis is based on the point estimates from the baseline specification (column 3 of Table 3). To arrive at nation-wide counterfactual election results, we weigh the predicted election results by the number of votes cast in each community. We assume that migrants would have had the average electoral preferences and voter turnout of their home communities. In the first type of scenario, we hold the level of migration flows constant, but change their direction. Scenario 1a) examines the case the case where all migrants to the West had gone to the East instead. Scenario 1b) examines the opposite case where all migrants to the East had gone to the West instead. In the second type of scenario, we change the level of migration flows. Scenario 2a) examines the case where all migrants to the West had never migrated and stayed in Moldova instead. Scenario 2b) examines the case where all migrants to the East had never migrated and stayed in Moldova instead. 
Table 8: Heterogeneity of the effect of migration patterns on Communist votes

\begin{tabular}{|c|c|c|c|c|c|c|c|}
\hline & \multirow[t]{2}{*}{$\begin{array}{l}\text { Only rural } \\
\text { communities }\end{array}$} & \multicolumn{2}{|c|}{$\begin{array}{l}\text { By share of } \\
\text { population who } \\
\text { grew up in the } \\
\text { Soviet Union } \\
\text { (were older than } \\
21 \text { years in 1991) }\end{array}$} & \multicolumn{2}{|c|}{$\begin{array}{l}\text { By share of } \\
\text { population with } \\
\text { higher education }\end{array}$} & \multirow[t]{2}{*}{$\begin{array}{l}\text { Non-linear } \\
\text { specification }\end{array}$} & \multirow[t]{2}{*}{$\begin{array}{l}\text { Hetero- } \\
\text { geneity } \\
\text { within the } \\
\text { West }\end{array}$} \\
\hline & & $\begin{array}{l}\text { below } \\
\text { median }\end{array}$ & $\begin{array}{l}\text { above } \\
\text { median }\end{array}$ & $\begin{array}{l}\text { below } \\
\text { median }\end{array}$ & $\begin{array}{l}\text { above } \\
\text { median }\end{array}$ & & \\
\hline & $(1)$ & $(2)$ & (3) & (4) & (5) & $(6)$ & $(7)$ \\
\hline $\begin{array}{l}\text { Prevalence of emigration to the } \\
\text { West }(\%)\end{array}$ & $\begin{array}{c}-0.73 * * * \\
(0.18)\end{array}$ & $\begin{array}{l}-0.37 * \\
(0.23)\end{array}$ & $\begin{array}{c}-0.89 * * * \\
(0.31)\end{array}$ & $\begin{array}{c}-0.66^{* * *} \\
(0.19)\end{array}$ & $\begin{array}{c}-0.41^{*} \\
(0.25)\end{array}$ & $\begin{array}{c}-1.29 * * * \\
(0.49)\end{array}$ & \\
\hline $\begin{array}{l}\text { Prevalence of emigration to the } \\
\text { East }(\%)\end{array}$ & $\begin{array}{c}0.52^{* * *} \\
(0.14)\end{array}$ & $\begin{array}{c}0.75^{* * *} \\
(0.21)\end{array}$ & $\begin{array}{c}0.08 \\
(0.19)\end{array}$ & $\begin{array}{c}0.52^{* *} \\
(0.23)\end{array}$ & $\begin{array}{c}0.32 \\
(0.25)\end{array}$ & $\begin{array}{c}0.93 * * * \\
(0.32)\end{array}$ & $\begin{array}{c}0.39 * * \\
(0.16)\end{array}$ \\
\hline $\begin{array}{l}\text { (Prevalence of emigration to the } \\
\text { West) })^{2}\end{array}$ & & & & & & $\begin{array}{c}-0.03 * * \\
(0.02)\end{array}$ & \\
\hline $\begin{array}{l}\text { (Prevalence of emigration to the } \\
\text { East })^{2}\end{array}$ & & & & & & $\begin{array}{c}-0.03^{* *} \\
(0.02)\end{array}$ & \\
\hline $\begin{array}{l}\text { Prevalence of emigration to full } \\
\text { Western democracies (\%) }\end{array}$ & & & & & & & $\begin{array}{c}-1.32^{* * * *} \\
(0.36)\end{array}$ \\
\hline $\begin{array}{l}\text { Prevalence of emigration to flawed } \\
\text { Western democracies }(\%)\end{array}$ & & & & & & & $\begin{array}{l}-0.33 \\
(0.22)\end{array}$ \\
\hline Full set of controls & yes & yes & yes & yes & yes & yes & yes \\
\hline District fixed effects & yes & yes & yes & yes & yes & yes & yes \\
\hline Number of observations & 803 & 424 & 424 & 424 & 424 & 848 & 848 \\
\hline $\mathrm{R}^{2}$ & 0.81 & 0.81 & 0.82 & 0.78 & 0.87 & 0.82 & 0.82 \\
\hline
\end{tabular}

The table reports OLS estimates. The dependent variable is the vote share of the Communist Party in the July 2009 parliamentary election at the community level (in percent). Column 1 excludes urban communities from the sample and is thus based on 803 rural communities only. For columns 2 and 3 as well as 4 and 5 , the total sample is split at the median of the respective variable. Column 7 distinguishes between full and flawed democracies within Western destinations based on the classification provided by the Economist Intelligence Unit's index of democracy of 2006 (the index is not available for earlier years). Full Western democracies include Portugal, Greece, Spain, France, Germany, the Czech Republic, Great Britain, Ireland, the United States, Belgium, Austria, Canada, Switzerland and the Netherlands. Flawed Western democracies include Italy, Romania, Israel, Cyprus, Bulgaria and Poland. Moldova is also classified as flawed democracy. Standard errors clustered at the district level in parentheses. ${ }^{* * *}$ denotes statistical significance at the 1 percent level, ** at the 5 percent level, and $*$ at the 10 percent level. 
Table 9: Migration patterns and individual political preferences over time, 2002-2009

\begin{tabular}{|c|c|c|c|c|c|c|}
\hline & $\begin{array}{l}\text { Vote for the } \\
\text { Communist } \\
\text { Party }\end{array}$ & $\begin{array}{l}\text { Satisfied } \\
\text { with life in } \\
\text { general }\end{array}$ & $\begin{array}{l}\text { Trust in } \\
\text { government }\end{array}$ & $\begin{array}{l}\text { Trust in } \\
\text { local media }\end{array}$ & $\begin{array}{l}\text { In favor of } \\
\text { government } \\
\text { intervention } \\
\text { in the } \\
\text { economy }\end{array}$ & $\begin{array}{l}\text { Would vote } \\
\text { in elections }\end{array}$ \\
\hline & (1) & $(2)$ & (3) & (4) & (5) & (6) \\
\hline $\begin{array}{l}\text { Prevalence of emigration to the } \\
\text { West }(\%)\end{array}$ & $\begin{array}{c}0.014 * * \\
(0.006)\end{array}$ & $\begin{array}{l}0.00)^{*} \\
(0.005)\end{array}$ & $\begin{array}{c}0.018^{* * *} \\
(0.006)\end{array}$ & $\begin{array}{c}0.011 \\
(0.007)\end{array}$ & $\begin{array}{c}0.006 \\
(0.007)\end{array}$ & $\begin{array}{c}0.006 \\
(0.011)\end{array}$ \\
\hline $\begin{array}{l}\text { Prevalence of emigration to the } \\
\text { East }(\%)\end{array}$ & $\begin{array}{l}-0.008 \\
(0.005)\end{array}$ & $\begin{array}{l}-0.002 \\
(0.004)\end{array}$ & $\begin{array}{l}-0.008 \\
(0.005)\end{array}$ & $\begin{array}{l}-0.002 \\
(0.007)\end{array}$ & $\begin{array}{l}-0.003 \\
(0.004)\end{array}$ & $\begin{array}{c}-0.017 * * \\
(0.008)\end{array}$ \\
\hline Years since 2002 & $\begin{array}{l}-0.004 \\
(0.005)\end{array}$ & $\begin{array}{c}0.014 * * \\
(0.006)\end{array}$ & $\begin{array}{c}-0.019 * * * \\
(0.006)\end{array}$ & $\begin{array}{c}0.022 * * \\
(0.010)\end{array}$ & $\begin{array}{c}0.002 \\
(0.006)\end{array}$ & $\begin{array}{l}0.021 * \\
(0.011)\end{array}$ \\
\hline $\begin{array}{l}\text { Prevalence of emigration to the } \\
\text { West } * \text { years }\end{array}$ & $\begin{array}{c}-0.003^{* *} \\
(0.001)\end{array}$ & $\begin{array}{c}-0.002^{* * *} \\
(0.001)\end{array}$ & $\begin{array}{c}-0.002 * * \\
(0.001)\end{array}$ & $\begin{array}{c}-0.003^{* *} \\
(0.001)\end{array}$ & $\begin{array}{l}-0.003 * \\
(0.001)\end{array}$ & $\begin{array}{l}-0.000 \\
(0.002)\end{array}$ \\
\hline $\begin{array}{l}\text { Prevalence of emigration to the } \\
\text { East * years }\end{array}$ & $\begin{array}{c}0.001 \\
(0.001)\end{array}$ & $\begin{array}{l}-0.001 \\
(0.001)\end{array}$ & $\begin{array}{c}0.001 \\
(0.001)\end{array}$ & $\begin{array}{l}-0.000 \\
(0.002)\end{array}$ & $\begin{array}{c}0.001 \\
(0.001)\end{array}$ & $\begin{array}{l}0.003^{*} \\
(0.001)\end{array}$ \\
\hline Individual characteristics & yes & yes & yes & yes & yes & yes \\
\hline Community characteristics & yes & yes & yes & yes & yes & yes \\
\hline District fixed effects & yes & yes & yes & yes & yes & yes \\
\hline Number of observations & 5,480 & 8,350 & 8,350 & 8,350 & 8,350 & 8,350 \\
\hline $\mathrm{R}^{2}$ & 0.14 & 0.03 & 0.09 & 0.05 & 0.03 & 0.03 \\
\hline
\end{tabular}

The table reports OLS estimates for 8,350 individuals using data from several rounds of the Moldovan Political Barometer, a regular public opinion poll on socio-political issues. The sample is based on a pooled cross-section of all rounds conducted between April 2002 and March 2009. The dependent variables are whether an individual would have voted for the Communist Party should there be elections next Sunday (column 1), is satisfied with life in general (column 2), has trust in the government (column 3), has trust in local media (column 4), would like the state to play an increased role to improve socio-economic conditions (column 5), and would vote should there be elections next Sunday (column 6). Marginal effects from a probit model are very similar and available upon request. Standard errors clustered at the community level in parentheses. *** denotes statistical significance at the 1 percent level, ** at the 5 percent level, and * at the 10 percent level. 
Table 10: Transmission channels of the effect of migration patterns on Communist votes

\begin{tabular}{|c|c|c|c|}
\hline & $\begin{array}{c}\text { Dependent variable: } \\
\text { Voter turnout } \\
\text { July } 2009\end{array}$ & $\begin{array}{l}\text { Baseline specification } \\
\text { (Communist votes in } \\
\text { July 2009) } \\
\text { with control for voter } \\
\text { turnout in July } 2009\end{array}$ & $\begin{array}{l}\text { Baseline specification } \\
\text { (Communist votes in } \\
\text { July 2009) } \\
\text { with controls for local } \\
\text { economic conditions in } \\
2009\end{array}$ \\
\hline & (1) & (2) & (3) \\
\hline Prevalence of emigration to the West (\%) & $\begin{array}{c}-0.52^{* * *} \\
(0.08)\end{array}$ & $\begin{array}{c}-0.60 * * * \\
(0.17)\end{array}$ & $\begin{array}{c}-0.65^{* * *} \\
(0.18)\end{array}$ \\
\hline Prevalence of emigration to the East ( $\%)$ & $\begin{array}{c}-0.31^{* * *} \\
(0.09)\end{array}$ & $\begin{array}{c}0.40 * * \\
(0.15) \\
\end{array}$ & $\begin{array}{c}0.36^{* *} \\
(0.16) \\
\end{array}$ \\
\hline Full set of controls & yes & yes & yes \\
\hline District fixed effects & yes & yes & yes \\
\hline Control for voter turnout 2009 & - & yes & - \\
\hline Controls for economic conditions 2009 & - & - & yes \\
\hline Number of observations & 848 & 848 & 848 \\
\hline $\mathrm{R}^{2}$ & 0.49 & 0.82 & 0.82 \\
\hline
\end{tabular}

The table reports OLS estimates for 848 Moldovan communities. The dependent variables are voter turnout in the July 2009 parliamentary election (in percent) (column 1), and the vote share of the Communist Party in the July 2009 parliamentary election (in percent) (columns 2 and 3). Compared to our baseline specification (column 3 of Table 3 ), in column 2 we also control for voter turnout in July 2009. In column 3, we also control for community-level night-time light intensity, per-capita tax revenues, unemployment rate and the per-capita number of shops in 2009. The three latter variables are based on statistics published by the Moldovan Ministry of Economy and Trade. Standard errors clustered at the district level in parentheses. ${ }^{* *}$ denotes statistical significance at the 1 percent level, ** at the 5 percent level, and $*$ at the 10 percent level. 
Table 11: Individual-level migration patterns and Communist votes in 2010 (exit poll)

\begin{tabular}{|c|c|c|c|c|c|}
\hline & $\begin{array}{l}\text { Individual } \\
\text { controls }\end{array}$ & $\begin{array}{l}\text { Plus } \\
\text { community } \\
\text { fixed effects }\end{array}$ & $\begin{array}{l}\text { Only } \\
\text { individuals } \\
\text { with family } \\
\text { in the West }\end{array}$ & $\begin{array}{l}\text { Only } \\
\text { individuals } \\
\text { with family } \\
\text { in the East }\end{array}$ & $\begin{array}{l}\text { Only non- } \\
\text { migrants } \\
\text { without } \\
\text { family } \\
\text { abroad }\end{array}$ \\
\hline & (1) & $(2)$ & (3) & (4) & $(5)$ \\
\hline Returned emigrant from the West & $\begin{array}{c}-0.087 * * * \\
(0.014)\end{array}$ & $\begin{array}{c}-0.068 * * * \\
(0.014)\end{array}$ & & & \\
\hline Returned emigrant from the East & $\begin{array}{c}0.014 \\
(0.016)\end{array}$ & $\begin{array}{c}0.010 \\
(0.014)\end{array}$ & & & \\
\hline With close family member in the West & $\begin{array}{c}-0.121 * * * \\
(0.013)\end{array}$ & $\begin{array}{c}-0.079 * * * \\
(0.016)\end{array}$ & & & \\
\hline With close family member in the East & $\begin{array}{c}0.007 \\
(0.015)\end{array}$ & $\begin{array}{c}0.001 \\
(0.013)\end{array}$ & & & \\
\hline $\begin{array}{l}\text { With close family members in both the West } \\
\text { and East }\end{array}$ & $\begin{array}{c}-0.077 * * * \\
(0.012)\end{array}$ & $\begin{array}{c}-0.072 * * * \\
(0.013)\end{array}$ & & & \\
\hline Prevalence of emigration to the West (\%) & & & $\begin{array}{l}-0.013 \\
(0.010)\end{array}$ & $\begin{array}{l}-0.031 * * * \\
(0.006)\end{array}$ & $\begin{array}{l}-0.021 * * * \\
(0.007)\end{array}$ \\
\hline Prevalence of emigration to the East (\%) & & & $\begin{array}{c}0.014 \\
(0.009)\end{array}$ & $\begin{array}{c}0.001 \\
(0.004)\end{array}$ & $\begin{array}{c}0.001 \\
(0.005)\end{array}$ \\
\hline Individual characteristics & yes & yes & yes & yes & yes \\
\hline Community fixed effects & - & yes & - & - & - \\
\hline Number of observations & 7,344 & 7,344 & 1,194 & 2,327 & 3,051 \\
\hline $\mathrm{R}^{2}$ & 0.18 & 0.22 & 0.17 & 0.21 & 0.21 \\
\hline
\end{tabular}

The table reports OLS estimates for 7,344 individuals using data from an exit poll conducted during the parliamentary election of November of 2010. The dependent variable is a binary variable indicating whether an individual voted for the Communist Party. Marginal effects from a probit model are very similar and are available upon request. Standard errors clustered at the community level in parentheses. *** denotes statistical significance at the 1 percent level, ** at the 5 percent level, and $*$ at the 10 percent level. 
Table A1: Determinants of migration patterns at the community level

\begin{tabular}{|c|c|c|c|c|c|c|c|c|}
\hline & \multirow{2}{*}{\multicolumn{2}{|c|}{$\begin{array}{c}\text { Overall } \\
\text { prevalence of } \\
\text { emigration }\end{array}$}} & \multirow{2}{*}{\multicolumn{2}{|c|}{$\begin{array}{c}\text { Share of west- } \\
\text { ward migrants } \\
\text { among migrants } \\
(2)\end{array}$}} & \multirow{2}{*}{\multicolumn{2}{|c|}{$\begin{array}{c}\begin{array}{c}\text { Prevalence of } \\
\text { emigration to } \\
\text { the West }\end{array} \\
\text { (3) } \\
\end{array}$}} & \multirow{2}{*}{\multicolumn{2}{|c|}{$\begin{array}{c}\begin{array}{c}\text { Prevalence of } \\
\text { emigration to } \\
\text { the East }\end{array} \\
\text { (4) }\end{array}$}} \\
\hline & & & & & & & & \\
\hline & coef. & s.e. & coef. & s.e. & coef. & s.e. & coef. & s.e. \\
\hline Communist Party $1998(\%)$ & 0.00 & $(0.01)$ & -0.14 & $(0.08)$ & -0.01 & $(0.01)$ & 0.01 & $(0.01)$ \\
\hline Democratic Party $1998(\%)$ & 0.01 & $(0.01)$ & 0.05 & $(0.07)$ & 0.01 & $(0.01)$ & -0.01 & $(0.01)$ \\
\hline Democratic Convention 1998 (\%) & $0.03^{* * *}$ & $(0.01)$ & 0.03 & $(0.09)$ & $0.01 *$ & $(0.01)$ & $0.02 *$ & $(0.01)$ \\
\hline Party of Democratic Forces 1998 (\%) & 0.00 & $(0.02)$ & 0.07 & $(0.10)$ & 0.01 & $(0.01)$ & -0.01 & $(0.01)$ \\
\hline Voter turnout $1998(\%)$ & -0.01 & $(0.02)$ & 0.01 & $(0.09)$ & -0.00 & $(0.01)$ & -0.01 & $(0.01)$ \\
\hline Democratic Agrarian Party 1994 (\%) & -0.00 & $(0.01)$ & $0.10^{*}$ & $(0.05)$ & 0.01 & $(0.01)$ & -0.01 & $(0.01)$ \\
\hline Socialist Party 1994 (\%) & -0.00 & $(0.01)$ & $0.11 * *$ & $(0.05)$ & 0.01 & $(0.01)$ & -0.01 & $(0.01)$ \\
\hline Peasants and Intellectuals Bloc 1994 (\%) & -0.02 & $(0.02)$ & $0.25^{* *}$ & $(0.12)$ & 0.01 & $(0.01)$ & $-0.03^{*}$ & $(0.02)$ \\
\hline Alliance Pop. Christian Dem. Front 1994 (\%) & $-0.06 * *$ & $(0.03)$ & 0.13 & $(0.14)$ & -0.02 & $(0.01)$ & $-0.05^{* *}$ & $(0.02)$ \\
\hline Change night-time light 1992-1999 & $-0.11 *$ & $(0.06)$ & -0.18 & $(0.26)$ & -0.05 & $(0.03)$ & -0.05 & $(0.05)$ \\
\hline Community size 1501-3000 & -0.19 & $(0.34)$ & $3.16^{* * *}$ & $(1.24)$ & 0.28 & $(0.19)$ & $-0.48^{*}$ & $(0.26)$ \\
\hline Community size $>3000$ & -0.59 & $(0.41)$ & $6.53^{* * *}$ & $(1.34)$ & $0.40^{*}$ & $(0.22)$ & $-0.99 * * *$ & $(0.29)$ \\
\hline District capital & $-3.83 * * *$ & $(1.13)$ & 2.28 & $(3.45)$ & -0.14 & $(0.62)$ & $-3.69 * * *$ & $(0.97)$ \\
\hline Distance to district capital (km) & $-0.07 * * *$ & $(0.02)$ & 0.09 & $(0.10)$ & $-0.03 * *$ & $(0.01)$ & $-0.05^{* * *}$ & $(0.02)$ \\
\hline Distance to Romanian border crossing (km) & $-0.01 * * *$ & $(0.01)$ & -0.10 & $(0.10)$ & $-0.02 * *$ & $(0.01)$ & $0.00^{* * *}$ & $(0.02)$ \\
\hline Chisinau/Balti & $-7.70^{*}$ & $(3.89)$ & 8.26 & $(6.38)$ & -0.63 & $(1.37)$ & $-7.07 * *$ & $(3.40)$ \\
\hline Population $0-14$ years $(\%)$ & $-0.27 * * *$ & $(0.06)$ & $-0.65^{*}$ & $(0.37)$ & $-0.15^{* * *}$ & $(0.04)$ & $-0.12^{*}$ & $(0.07)$ \\
\hline Population $15-34$ years (\%) & $0.18^{* *}$ & $(0.07)$ & -0.38 & $(0.37)$ & 0.06 & $(0.05)$ & $0.12^{* *}$ & $(0.06)$ \\
\hline Population 65 years and older $(\%)$ & $-0.24 * * *$ & $(0.08)$ & -0.28 & $(0.33)$ & -0.03 & $(0.04)$ & $-0.21 * * *$ & $(0.07)$ \\
\hline Population with higher education (\%) & 0.07 & $(0.07)$ & $0.59 * * *$ & $(0.20)$ & $0.10^{* * *}$ & $(0.03)$ & -0.03 & $(0.06)$ \\
\hline Population with primary or no education (\%) & -0.01 & $(0.02)$ & -0.03 & $(0.09)$ & -0.00 & $(0.01)$ & -0.00 & $(0.02)$ \\
\hline Ratio high-skilled/low-skilled & 0.49 & $(1.77)$ & -3.63 & $(4.12)$ & -0.92 & $(0.88)$ & 1.41 & $(1.43)$ \\
\hline Ethnic Russians (\%) & -0.03 & $(0.11)$ & $-1.22^{* * *}$ & $(0.42)$ & $-0.19 * * *$ & $(0.07)$ & $0.16^{*}$ & $(0.09)$ \\
\hline (Ethnic Russians) $^{2}$ & -0.00 & $(0.00)$ & $0.01 * * *$ & $(0.00)$ & $0.00^{* * *}$ & $(0.00)$ & $-0.00 * *$ & $(0.00)$ \\
\hline Ethnic Ukrainians (\%) & -0.06 & $(0.05)$ & -0.10 & $(0.24)$ & $-0.07 * *$ & $(0.04)$ & 0.01 & $(0.05)$ \\
\hline 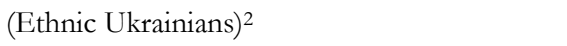 & 0.00 & $(0.00)$ & 0.00 & $(0.00)$ & $0.00^{*}$ & $(0.00)$ & -0.00 & $(0.00)$ \\
\hline Ethnic Gagauz (\%) & -0.02 & $(0.05)$ & $-0.72 * *$ & $(0.32)$ & $-0.11 * *$ & $(0.04)$ & 0.09 & $(0.06)$ \\
\hline$(\text { Ethnic Gagauz) })^{2}$ & $0.00^{* *}$ & $(0.00)$ & 0.00 & $(0.00)$ & $0.00^{* *}$ & $(0.00)$ & 0.00 & $(0.00)$ \\
\hline Ethnic Bulgarians (\%) & -0.06 & $(0.05)$ & -0.01 & $(0.28)$ & -0.04 & $(0.03)$ & -0.01 & $(0.05)$ \\
\hline (Ethnic Bulgarians) $^{2}$ & 0.00 & $(0.00)$ & -0.00 & $(0.00)$ & 0.00 & $(0.00)$ & 0.00 & $(0.00)$ \\
\hline Ethnic fractionalization & $5.81 * * *$ & $(1.86)$ & -4.80 & $(12.36)$ & $3.08^{* *}$ & $(1.61)$ & 2.73 & $(1.68)$ \\
\hline Constant & 13.46 & $(4.43)$ & $50.22^{* * *}$ & $(18.20)$ & 4.35 & $(2.34)$ & 9.12 & (3.88) \\
\hline District fixed effects & ye & & ye & & ye & & & \\
\hline Number of observations & 84 & & 84 & & 84 & & 84 & \\
\hline $\mathrm{R}^{2}$ & 0.3 & & $0 .($ & & 0.5 & & 0.4 & \\
\hline
\end{tabular}

The table reports OLS estimates of the determinants of migration patterns for 848 communities using the same set of explanatory variables as in our baseline specification in the main analysis (column 3 of Table 3). The prevalence of emigration is measured as the share of migrants as percent of the total population. The share of westward migrants among all migrants is measured in percent. Standard errors clustered at the district level in parentheses. *** denotes statistical significance at the 1 percent level, ** at the 5 percent level, and $*$ at the 10 percent level. 
Table A2: Night-time light intensity as a proxy for economic conditions at the community level

\begin{tabular}{lccc}
\hline & $\begin{array}{c}\text { Per-capita tax } \\
\text { revenues 2009 }\end{array}$ & $\begin{array}{c}\text { Unemployment } \\
\text { rate 2009 }\end{array}$ & $\begin{array}{c}\text { Per-capita number of } \\
\text { shops 2009 }\end{array}$ \\
\cline { 2 - 4 } & $(1)$ & $(2)$ & $(3)$ \\
\hline Night-time light 2009 & $0.012^{* * *}$ & $-0.597 * * *$ & $1.06 \mathrm{E}-04^{* * *}$ \\
& $(0.003)$ & $(0.224)$ & $(4.78 \mathrm{E}-05)$ \\
Community size 1501-3000 & $-0.025^{* * *}$ & $-2.769^{*}$ & $-2.50 \mathrm{E}-04^{*}$ \\
& $(0.009)$ & $(1.573)$ & $(1.38 \mathrm{E}-04)$ \\
Community size $>3000$ & 0.008 & -1.723 & $0.001^{* * *}$ \\
& $(0.013)$ & $(1.824)$ & $(0.000)$ \\
Chisinau/Balti & $0.762^{* * *}$ & 1.210 & $-0.005^{*}$ \\
Constant & $(0.250)$ & $(7.428)$ & $(0.003)$ \\
\hline Number of observations & $0.204^{* * *}$ & $21.186^{* * *}$ & $0.003^{* * *}$ \\
$\mathrm{R}^{2}$ & $(0.007)$ & $(1.300)$ & $(0.000)$ \\
\hline
\end{tabular}

The table reports OLS estimates for 848 Moldovan communities. The dependent variables are the per-capita tax revenues (column 1), the unemployment rate (column 2), and the per-capita number of shops in 2009 (column 3). These variables are based on statistics published by the Moldovan Ministry of Economy and Trade. Standard errors clustered at the district level in parentheses. ${ }^{* * *}$ denotes statistical significance at the 1 percent level, ${ }^{* *}$ at the 5 percent level, and ${ }^{*}$ at the 10 percent level. 
Table A3: Full regression results of columns 1-3 of Table 3

\begin{tabular}{|c|c|c|c|c|c|c|}
\hline & \multirow{2}{*}{\multicolumn{2}{|c|}{$\begin{array}{c}\text { Basic controls } \\
(1)\end{array}$}} & \multirow{2}{*}{\multicolumn{2}{|c|}{$\begin{array}{l}\begin{array}{c}\text { Plus pre-migration } \\
\text { election results }\end{array} \\
\text { (2) }\end{array}$}} & \multirow{2}{*}{\multicolumn{2}{|c|}{$\begin{array}{c}\begin{array}{c}\text { Plus night-time } \\
\text { light (full model) }\end{array} \\
\text { (3) }\end{array}$}} \\
\hline & & & & & & \\
\hline & coef. & s.e. & coef. & s.e. & coef. & s.e. \\
\hline Prevalence of emigration to the West (\%) & $-0.70 * * *$ & $(0.20)$ & $-0.63^{* * *}$ & $(0.18)$ & $-0.63^{* * *}$ & $(0.18)$ \\
\hline Prevalence of emigration to the East (\%) & $0.44 * *$ & $(0.17)$ & $0.39 * *$ & $(0.16)$ & $0.39 * *$ & $(0.16)$ \\
\hline Community size $1501-3000$ & -1.36 & $(1.01)$ & $-1.93 * *$ & $(0.99)$ & $-1.94 * *$ & $(0.99)$ \\
\hline Community size $>3000$ & $-2.66^{* *}$ & $(1.16)$ & $-2.28^{*}$ & $(1.20)$ & $-2.27 *$ & $(1.20)$ \\
\hline District capital & 0.37 & $(2.34)$ & -1.18 & $(1.91)$ & -1.31 & $(2.03)$ \\
\hline Distance to district capital $(\mathrm{km})$ & 0.00 & $(0.08)$ & -0.00 & $(0.07)$ & -0.00 & $(0.07)$ \\
\hline Distance to Romanian border crossing $(\mathrm{km})$ & 0.03 & $(0.04)$ & 0.04 & $(0.04)$ & 0.04 & $(0.04)$ \\
\hline Chisinau/Balti & 8.15 & $(6.27)$ & 5.61 & $(4.79)$ & 5.45 & $(4.81)$ \\
\hline Population $0-14$ years (\%) & -0.01 & $(0.20)$ & 0.03 & $(0.18)$ & 0.05 & $(0.19)$ \\
\hline Population 15-34 years (\%) & 0.03 & $(0.22)$ & 0.15 & $(0.20)$ & 0.15 & $(0.20)$ \\
\hline Population 65 years and older $(\%)$ & -0.06 & $(0.23)$ & 0.18 & $(0.21)$ & 0.19 & $(0.21)$ \\
\hline Population with higher education (\%) & $-0.41 * * *$ & $(0.15)$ & $-0.27 *$ & $(0.15)$ & $-0.28^{*}$ & $(0.16)$ \\
\hline Population with primary or no education (\%) & $0.14 * * *$ & $(0.05)$ & $0.13^{* * *}$ & $(0.04)$ & $0.13^{* * *}$ & $(0.04)$ \\
\hline Ratio high-skilled/low-skilled & 3.38 & $(3.73)$ & 2.85 & $(3.00)$ & 2.98 & $(3.06)$ \\
\hline Ethnic Russians (\%) & $1.46^{* * *}$ & $(0.25)$ & $0.97 * * *$ & $(0.19)$ & $0.96^{* * *}$ & $(0.19)$ \\
\hline (Ethnic Russians) $^{2}$ & $-0.01 * * *$ & $(0.00)$ & $-0.01 * * *$ & $(0.00)$ & $-0.01 * * *$ & $(0.00)$ \\
\hline Ethnic Ukrainians (\%) & $1.18^{* * *}$ & $(0.16)$ & $0.66^{* * *}$ & $(0.14)$ & $0.67 * * *$ & $(0.13)$ \\
\hline (Ethnic Ukrainians) $^{2}$ & $-0.01 * * *$ & $(0.00)$ & $-0.00^{* * *}$ & $(0.00)$ & $-0.00^{* * *}$ & $(0.00)$ \\
\hline Ethnic Gagauz (\%) & $1.13^{* * *}$ & $(0.29)$ & $0.71^{* * *}$ & $(0.23)$ & $0.72^{* * *}$ & $(0.23)$ \\
\hline$(\text { Ethnic Gagauz })^{2}$ & $-0.01 * *$ & $(0.00)$ & $-0.00 *$ & $(0.00)$ & $-0.00^{*}$ & $(0.00)$ \\
\hline Ethnic Bulgarians (\%) & $1.21 * * *$ & $(0.20)$ & $0.65^{* * *}$ & $(0.13)$ & $0.65^{* * *}$ & $(0.13)$ \\
\hline${\text { (Ethnic Bulgarians) })^{2}}^{2}$ & $-0.01 * * *$ & $(0.00)$ & $-0.00 *$ & $(0.00)$ & $-0.00^{*}$ & $(0.00)$ \\
\hline Ethnic fractionalization & $-25.62^{* * *}$ & $(6.90)$ & $-13.34 * *$ & $(6.27)$ & $-13.52^{* *}$ & $(6.15)$ \\
\hline Communist Party $1998(\%)$ & & & $0.15^{* * *}$ & $(0.03)$ & $0.15^{* * *}$ & $(0.03)$ \\
\hline Democratic Party $1998(\%)$ & & & 0.03 & $(0.04)$ & 0.03 & $(0.04)$ \\
\hline Democratic Convention $1998(\%)$ & & & $-0.13^{* * *}$ & $(0.05)$ & $-0.13^{* * *}$ & $(0.05)$ \\
\hline Party of Democratic Forces $1998(\%)$ & & & -0.12 & $(0.07)$ & -0.12 & $(0.07)$ \\
\hline Voter turnout $1998(\%)$ & & & 0.00 & $(0.05)$ & 0.00 & $(0.05)$ \\
\hline Democratic Agrarian Party $1994(\%)$ & & & $0.08^{* *}$ & $(0.04)$ & $0.08^{* *}$ & $(0.04)$ \\
\hline Socialist Party $1994(\%)$ & & & $0.10^{* *}$ & $(0.05)$ & $0.10^{* *}$ & $(0.05)$ \\
\hline Peasants and Intellectuals Bloc $1994(\%)$ & & & -0.06 & $(0.06)$ & -0.06 & $(0.06)$ \\
\hline Alliance Pop. Christian Dem. Front 1994 (\%) & & & $-0.13^{*}$ & $(0.07)$ & $-0.13^{*}$ & $(0.08)$ \\
\hline Change night-time light 1992-1999 & & & & & -0.06 & $(0.15)$ \\
\hline Constant & $34.83^{* *}$ & $(12.08)$ & 22.89 & $(12.70)$ & 21.89 & (13.38) \\
\hline District fixed effects & ye & & ye & & & \\
\hline Number of observations & 84 & & 84 & & & \\
\hline $\mathrm{R}^{2}$ & 0.7 & & 0.8 & & & \\
\hline
\end{tabular}

The table reports the full OLS estimates of our baseline results summarized in Table 3 . The dependent variable is the vote share of the Communist Party in the July 2009 parliamentary election at the community level (in percent). Standard errors clustered at the district level in parentheses. ${ }^{* * *}$ denotes statistical significance at the 1 percent level, ${ }^{* *}$ at the 5 percent level, and * at the 10 percent level. 
Table A4: Robustness checks

\begin{tabular}{|c|c|c|c|c|c|c|c|c|}
\hline & $\begin{array}{l}\text { Fifth-order } \\
\text { polynomials of } \\
\text { all control } \\
\text { variables }\end{array}$ & $\begin{array}{l}\text { Control for } \\
\text { share of } \\
\text { Communist } \\
\text { votes in } 2001\end{array}$ & $\begin{array}{c}\text { Migrant } \\
\text { characteristics }\end{array}$ & $\begin{array}{l}\text { West: without } \\
\text { Italy }\end{array}$ & $\begin{array}{l}\text { West: better } \\
\text { rule of law } \\
\text { than Moldova }\end{array}$ & $\begin{array}{c}\text { Estimation in } \\
\text { first } \\
\text { differences }\end{array}$ & $\begin{array}{c}\text { Estimation } \\
\text { with share of } \\
\text { westward } \\
\text { migrants } \\
\text { among all } \\
\text { migrants } \\
\end{array}$ & $\begin{array}{c}\text { Exposure to } \\
\text { democracy } \\
\text { abroad }\end{array}$ \\
\hline & (1) & $(2)$ & (3) & (4) & (5) & (6) & $(7)$ & (8) \\
\hline $\begin{array}{l}\text { Prevalence of emigration to the } \\
\text { West }(\%)\end{array}$ & $\begin{array}{c}-0.54 * * * \\
(0.21)\end{array}$ & $\begin{array}{c}-0.76^{* * *} \\
(0.15)\end{array}$ & $\begin{array}{c}-0.86 * * * \\
(0.15)\end{array}$ & $\begin{array}{c}-1.22^{* * *} \\
(0.21)\end{array}$ & $\begin{array}{c}-0.63^{* * *} \\
(0.18)\end{array}$ & $\begin{array}{c}-0.87 * * * \\
(0.26)\end{array}$ & & \\
\hline $\begin{array}{l}\text { Prevalence of emigration to the } \\
\text { East }(\%)\end{array}$ & $\begin{array}{c}0.45^{* * *} \\
(0.16)\end{array}$ & $\begin{array}{c}0.41 * * * \\
(0.15)\end{array}$ & $\begin{array}{c}0.43^{* *} \\
(0.18)\end{array}$ & $\begin{array}{c}0.40^{* *} \\
(0.16)\end{array}$ & $\begin{array}{c}0.39 * * \\
(0.16)\end{array}$ & $\begin{array}{c}0.20 \\
(0.24)\end{array}$ & & \\
\hline $\begin{array}{l}\text { Overall prevalence of emigration } \\
(\%)\end{array}$ & & & & & & & $\begin{array}{l}0.03 \\
(0.14)\end{array}$ & $\begin{array}{c}4.74 * * * \\
(0.85)\end{array}$ \\
\hline $\begin{array}{l}\text { Share of westward migrants } \\
\text { among all migrants }(\%)\end{array}$ & & & & & & & $\begin{array}{c}-0.10 * * * \\
(0.03)\end{array}$ & \\
\hline Democracy abroad & & & & & & & & $\begin{array}{l}4.67 \\
(7.94)\end{array}$ \\
\hline $\begin{array}{l}\text { Overall prevalence of emigration * } \\
\text { democracy abroad }\end{array}$ & & & & & & & & $\begin{array}{l}-5.44 * * * \\
(0.97)\end{array}$ \\
\hline Full set of controls & yes & yes & yes & yes & yes & - & yes & yes \\
\hline District fixed effects & yes & yes & yes & yes & yes & - & yes & yes \\
\hline Number of observations & 848 & 847 & 847 & 848 & 848 & 848 & 847 & 848 \\
\hline $\mathrm{R}^{2}$ & 0.85 & 0.84 & 0.82 & 0.82 & 0.82 & 0.03 & 0.82 & 0.82 \\
\hline
\end{tabular}

The table reports OLS estimates for 848 Moldovan communities. The dependent variable is the vote share of the Communist Party in the July 2009 parliamentary election at the community level (in percent). See Appendix 2 (robustness checks) for more details on the different columns. Standard errors clustered at the district level in parentheses. $* * *$ denotes statistical significance at the 1 percent level, ** at the 5 percent level, and $*$ at the 10 percent level. 
Table A5: Migrant characteristics

\begin{tabular}{|c|c|c|c|c|c|}
\hline & \multirow[b]{2}{*}{ All migrants } & \multirow{2}{*}{$\begin{array}{l}\text { Migrants to } \\
\text { the East }\end{array}$} & \multicolumn{3}{|c|}{ Migrants to the West } \\
\hline & & & All & $\begin{array}{c}\text { Full } \\
\text { democracies }\end{array}$ & Flawed democracies \\
\hline \multicolumn{6}{|l|}{ Education } \\
\hline Compulsary secondary education & $36 \%$ & $42 \%$ & $26 \%$ & $25 \%$ & $26 \%$ \\
\hline Additional secondary education & $44 \%$ & $44 \%$ & $43 \%$ & $42 \%$ & $43 \%$ \\
\hline Higher education & $20 \%$ & $14 \%$ & $31 \%$ & $32 \%$ & $31 \%$ \\
\hline \multicolumn{6}{|l|}{ Age } \\
\hline 15-24 years & $30 \%$ & $34 \%$ & $21 \%$ & $23 \%$ & $20 \%$ \\
\hline $25-44$ years & $54 \%$ & $51 \%$ & $61 \%$ & $62 \%$ & $60 \%$ \\
\hline 45 years and older & $16 \%$ & $15 \%$ & $18 \%$ & $15 \%$ & $20 \%$ \\
\hline \multicolumn{6}{|l|}{ Sex } \\
\hline Male & $57 \%$ & $64 \%$ & $43 \%$ & $59 \%$ & $36 \%$ \\
\hline Female & $43 \%$ & $36 \%$ & $57 \%$ & $41 \%$ & $64 \%$ \\
\hline
\end{tabular}

The table shows the skill, age and sex distribution of Moldovan emigrants to the East and West. Data come from Moldova's population census of 2004. Following Table 1, destination countries are classified as East if they have a lower or equal level of democracy than Moldova (as measured by the 2004 Polity IV score). Countries are defined as West if they have a higher level of democracy than Moldova. Within Western destinations, the table distinguishes between full and flawed democracies based on the classification provided by the Economist Intelligence Unit's index of democracy of 2006 (the index is not available for earlier years). Full Western democracies include Portugal, Greece, Spain, France, Germany, the Czech Republic, Great Britain, Ireland, the United States, Belgium, Austria, Canada, Switzerland and the Netherlands. Flawed Western democracies include Italy, Romania, Israel, Cyprus, Bulgaria and Poland. Moldova is also classified as flawed democracy. 


\section{Figures (including appendix figures)}

Figure 1: Number of emigrants (bars) and volume of international phone calls to and from Moldova (lines), 1998-2010

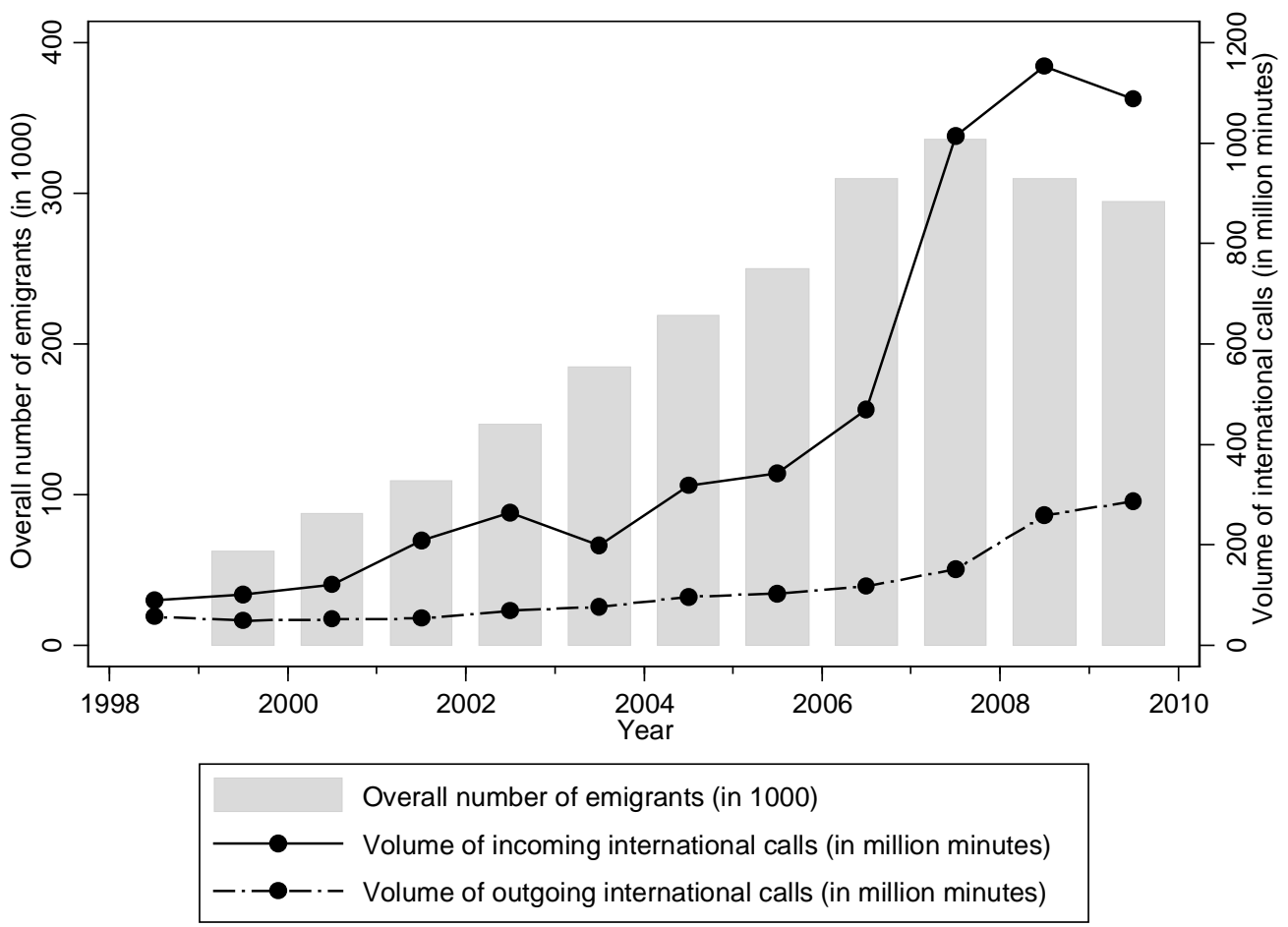

Bars represent the overall number of emigrants (in 1000). Data come from yearly waves of the Moldovan Labor Force Survey. Pre-2006 numbers of emigrants are adjusted to account for a change in the sampling method of the Moldovan Labor Force Survey. The first wave of the Moldovan Labor Force Survey was conducted in 1999, just after the unexpected Russian financial crisis hit Moldova in late 1998 and triggered the first big wave of emigration. Information on destination countries is not available in pre-2006 waves. Lines represent the volume of international calls (in million minutes). Data come the International Traffic Database compiled by Telegeography. 
Figure 2: Observed spatial patterns of emigration from Moldova:

Overall migration prevalence and share of westward migration across communities
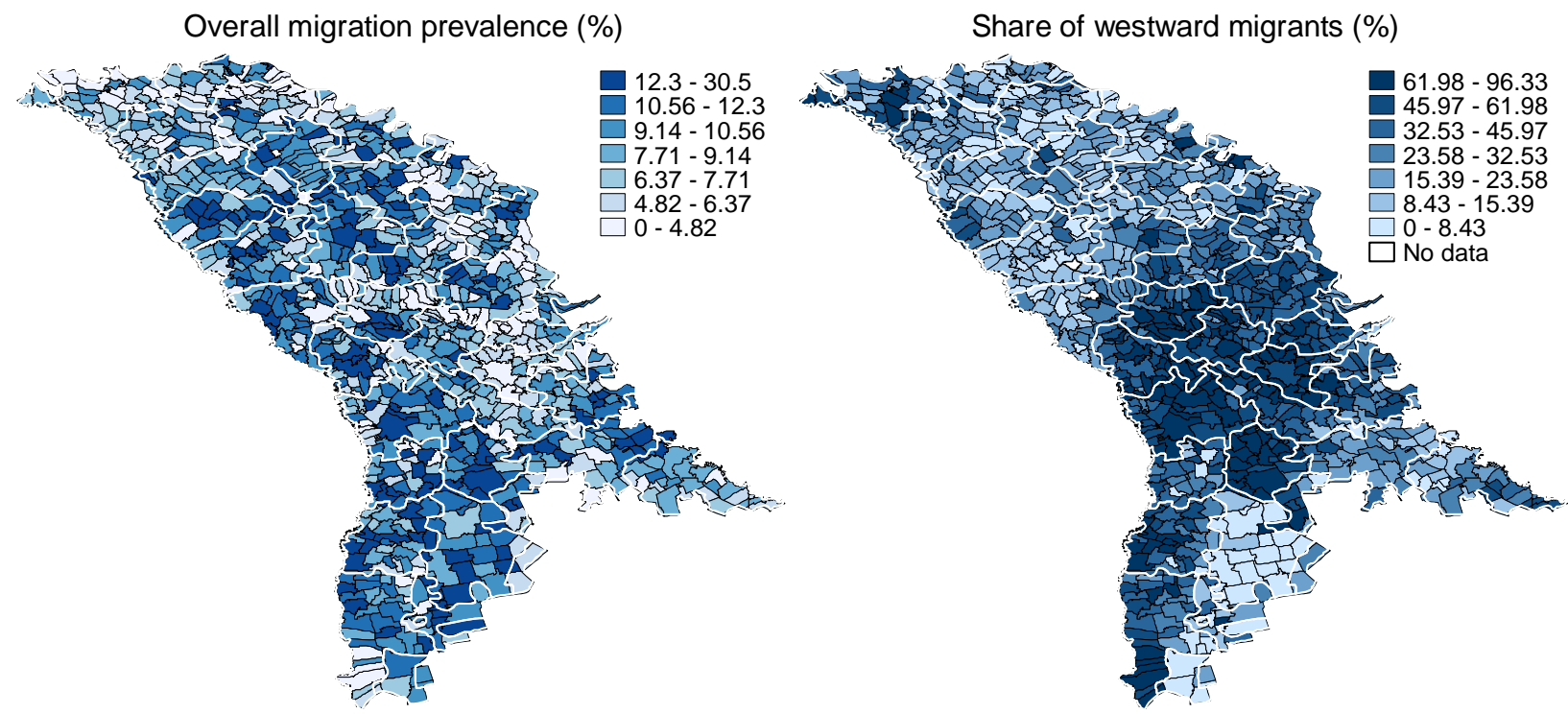

This figure shows a map of the observed overall migration prevalence (left panel) and the share of westward migrants (right panel) across Moldovan communities, based on the 2004 population census. Overall migration prevalence is the share of migrants as percent of the total population. The share of westward migrants is measured in percent of all migrants in the community. District borders are drawn in white.

Figure 3: Residual variation in spatial patterns of emigration from Moldova
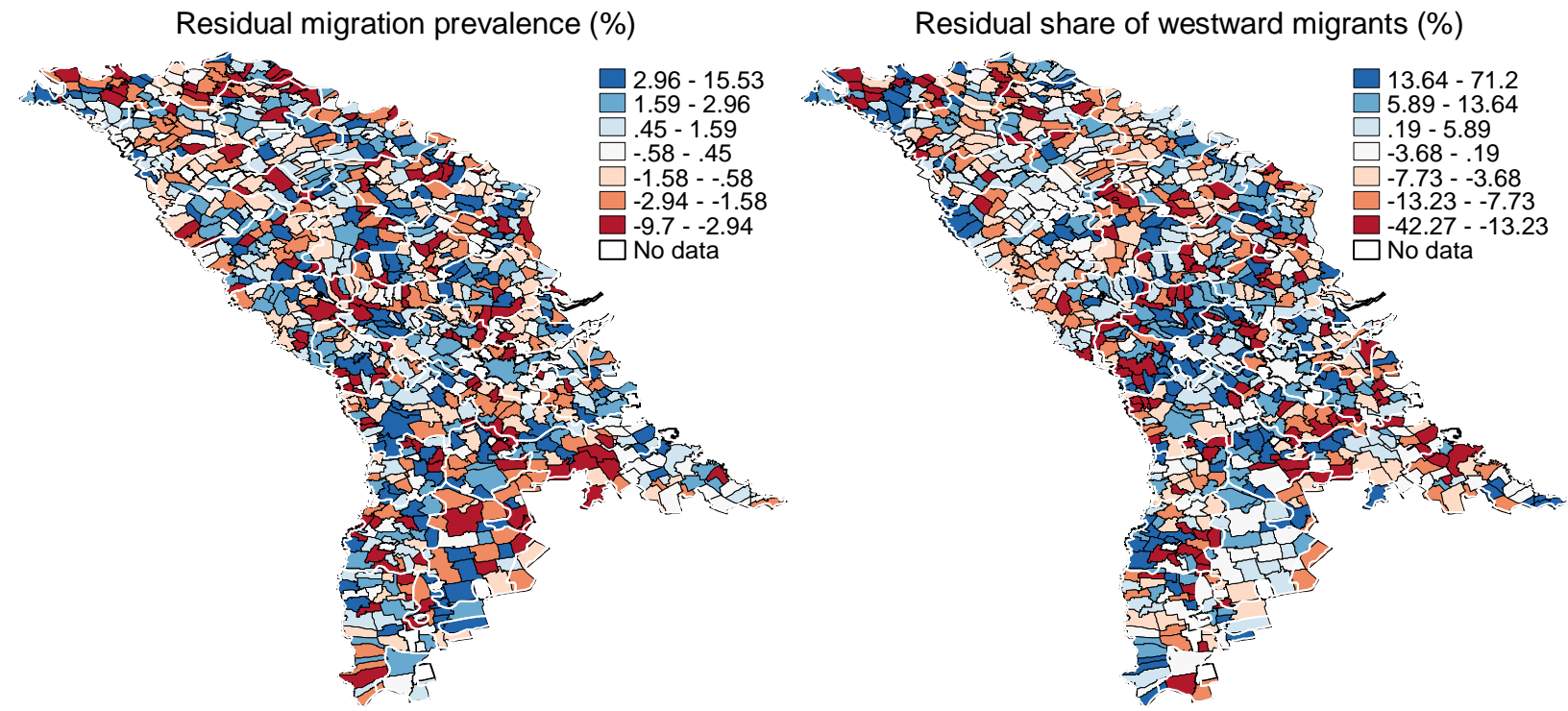

This figure shows a map of the residual variation in emigration patterns across Moldovan communities, after controlling for the full set of community-level variables of our baseline specification (column 3 of Table A3 in the appendix). The left panel shows residuals from a regression using overall migration prevalence as dependent variable (column 1 of Table A1 in the appendix). The right panel shows residuals from a regression using the share of westward migrants as dependent variable (column 2 of Table A1). 
Figure 4: Emigration in 2004 and share of Communist votes in July 2009 across communities

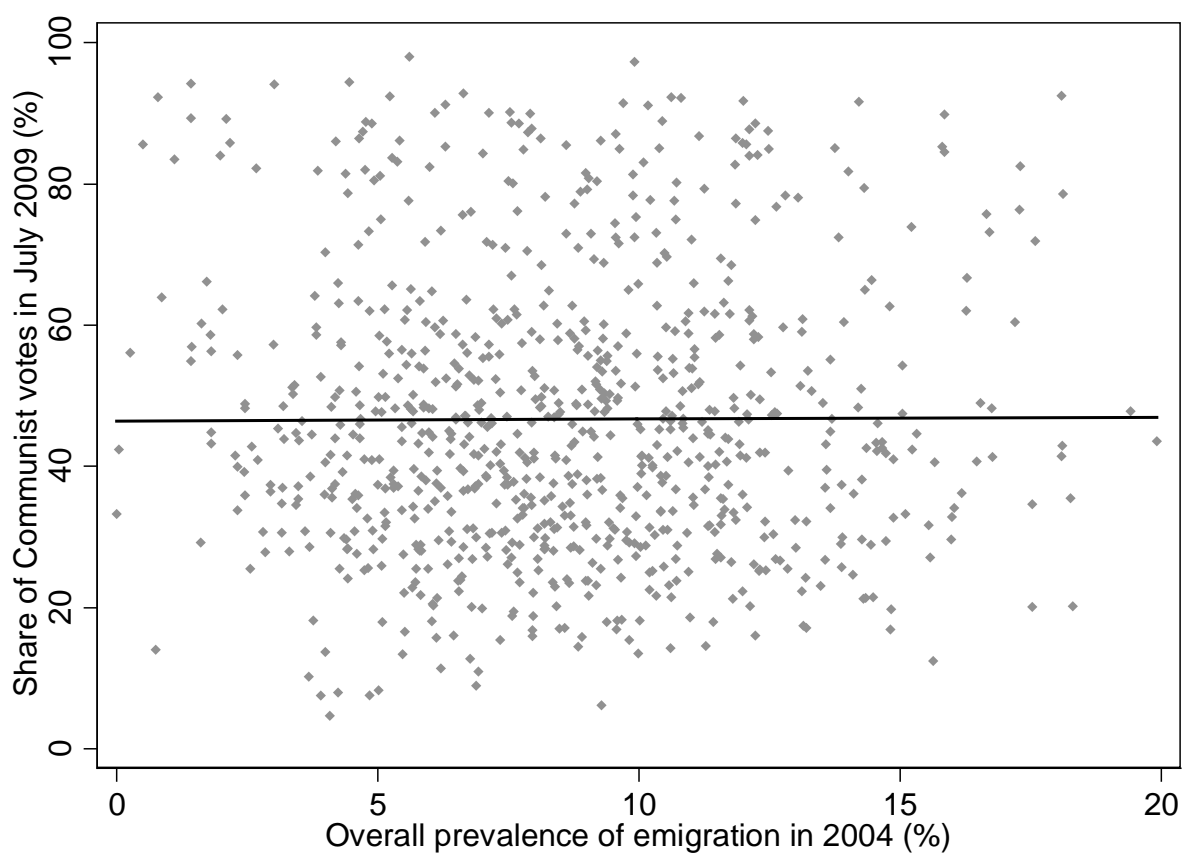

The figure shows the relationship between overall migration prevalence and the share of Communist votes across 848 Moldovan communities. The horizontal axis measures the overall share of migrants as percent of the total population (based on the 2004 population census). The vertical axis measures the share of Communist votes in the parliamentary elections of July 2009 (based on official election results). We only include votes cast in Moldova. Votes cast by migrants abroad are excluded. 
Figure 5: Westward migration in 2004 and share of Communist votes in 2009 across communities

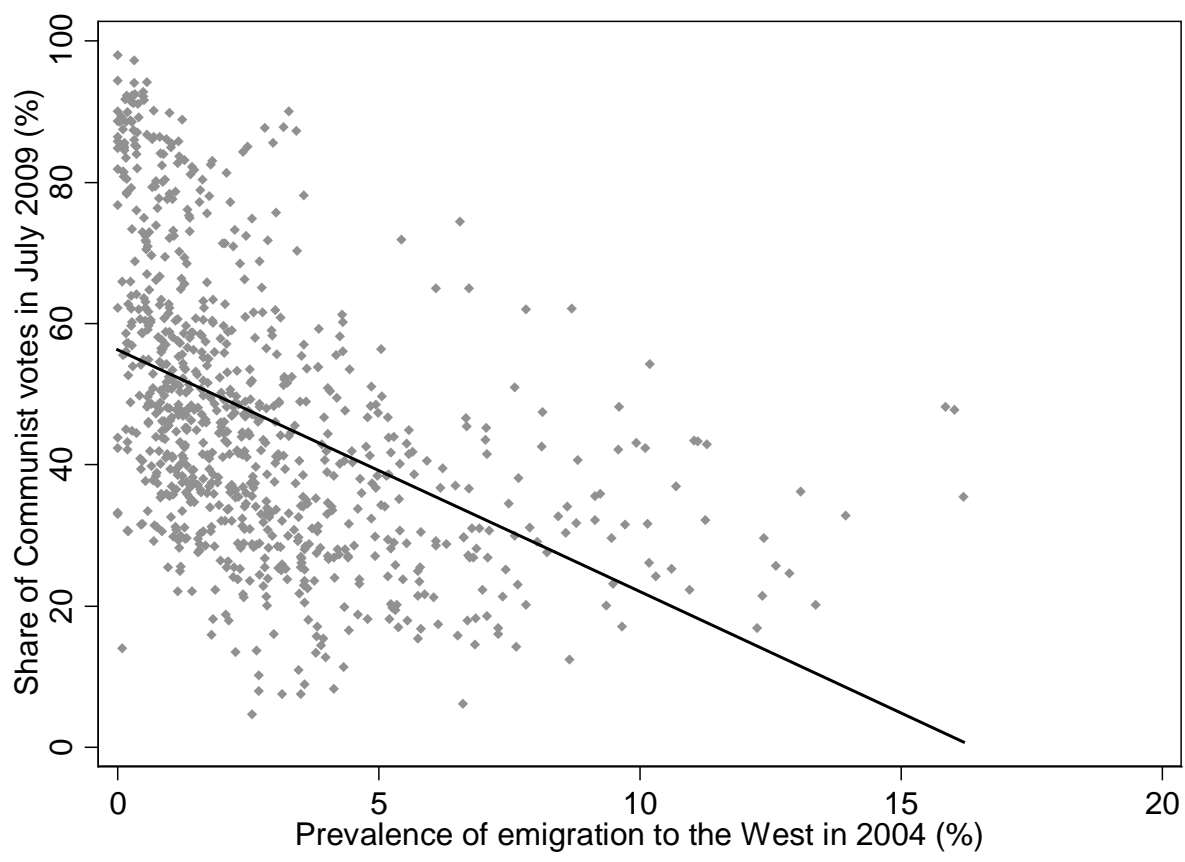

The figure shows the negative relationship between the prevalence of emigration to the West and the share of Communist votes across 848 Moldovan communities. The horizontal axis measures the share of migrants to the West as percent of the total population (based on the 2004 population census). The vertical axis measures the share of Communist votes in the parliamentary elections of July 2009 (based on official election results). We only include votes cast in Moldova. Votes cast by migrants abroad are excluded. 
Figure 6: Eastward migration in 2004 and share of Communist votes in 2009 across communities

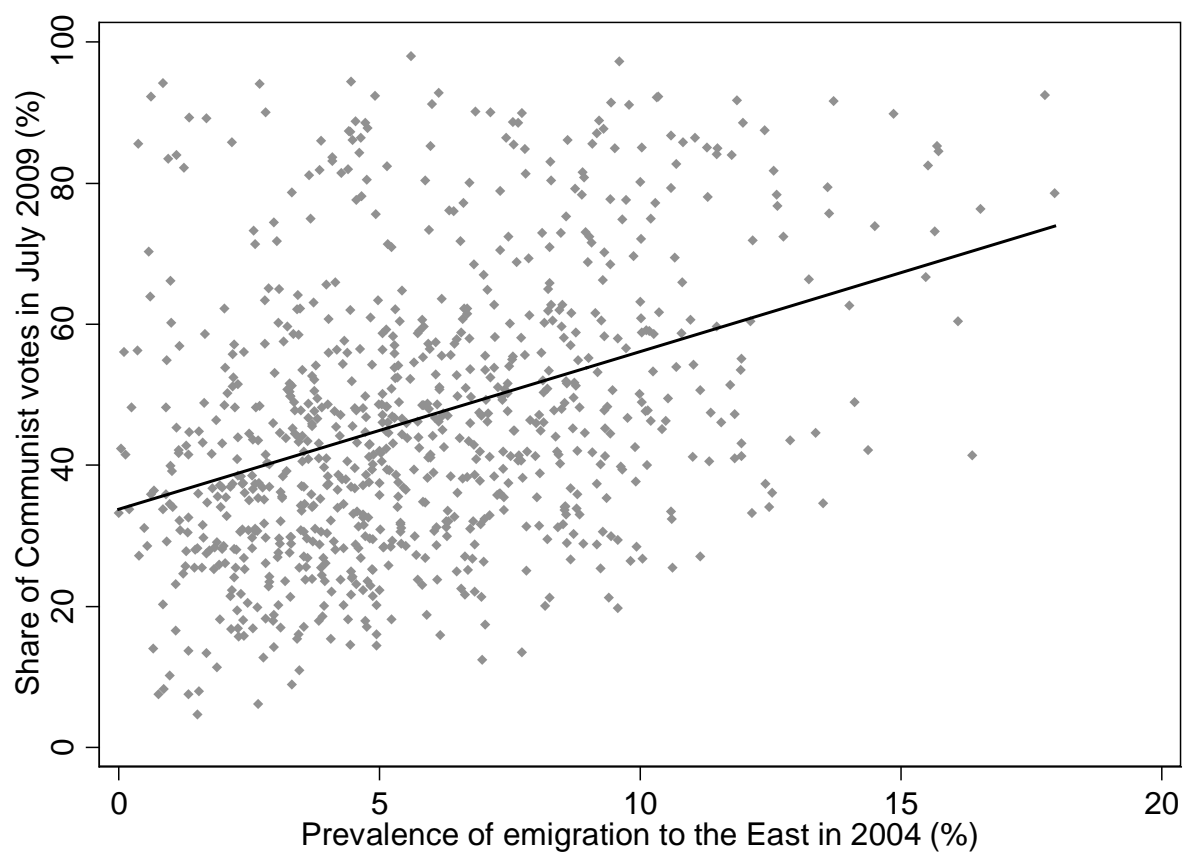

The figure shows the positive relationship between the prevalence of emigration to the East and the share of Communist votes across 848 Moldovan communities. The horizontal axis measures the share of migrants to the East as percent of the total population (based on the 2004 population census). The vertical axis measures the share of Communist votes in the parliamentary elections of July 2009 (based on official election results). We only include votes cast in Moldova. Votes cast by migrants abroad are excluded. 
Figure A1: Night-time light intensity of Moldovan communities in 1992 and 1999

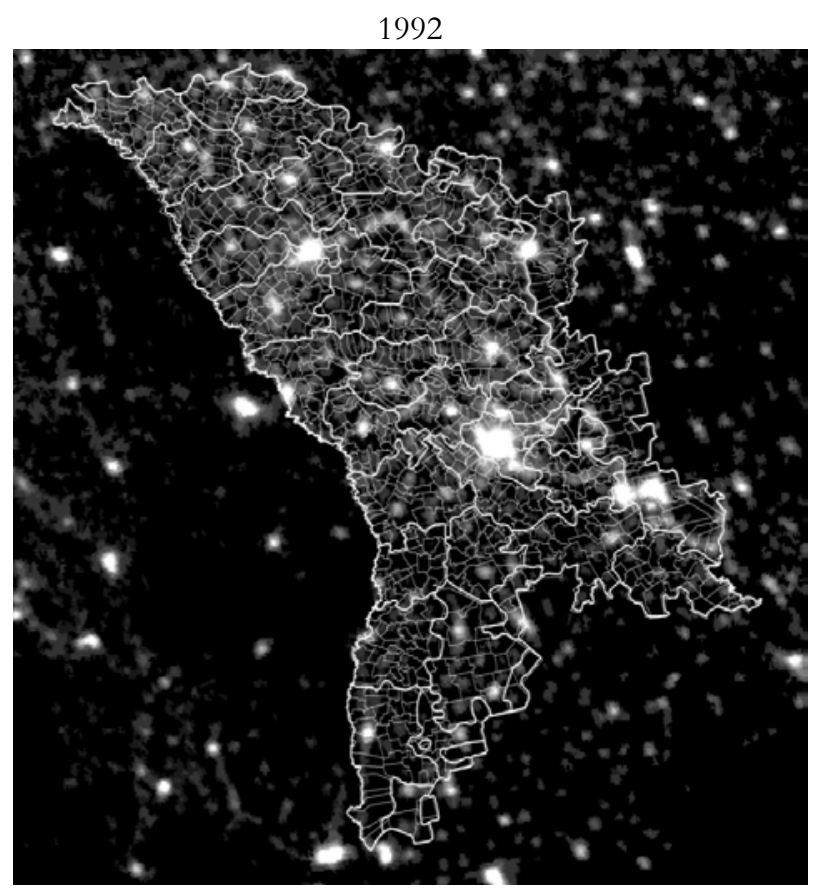

The images are based on data from the Defense Meteorological Satellite Program's Operational Linescan System. District borders are drawn in white.

Figure A2: Moldovan districts on a grid with 30x30 and 15x15 kilometer cells

30x30 kilometer (18.6x18.6 miles) grid cells

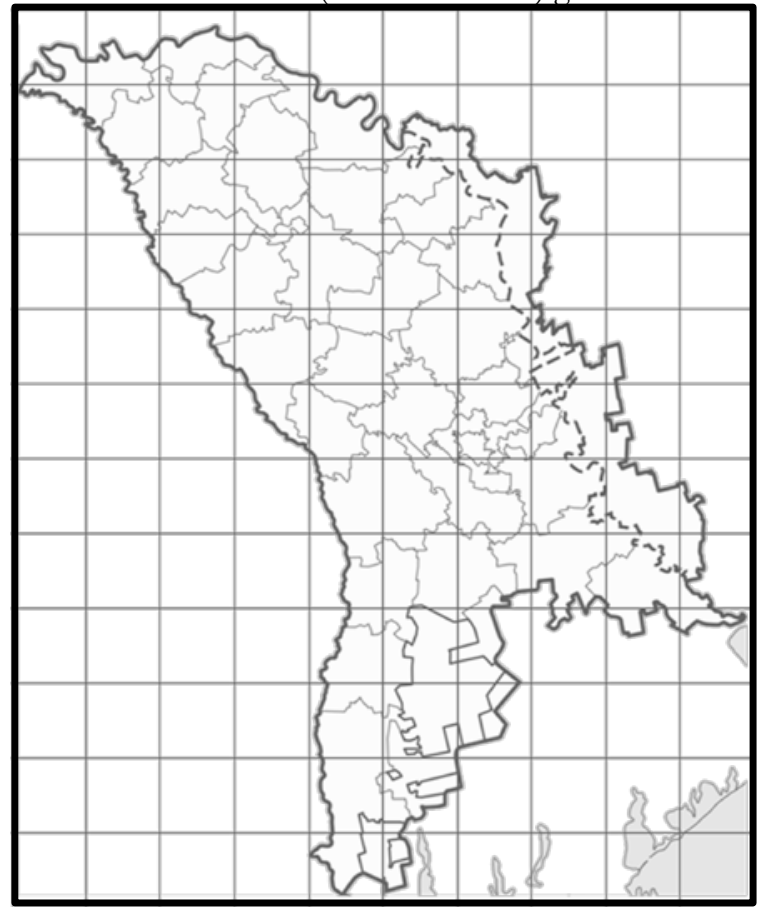

$15 \times 15$ kilometer $(9.3 \times 9.3$ miles $)$ grid cells

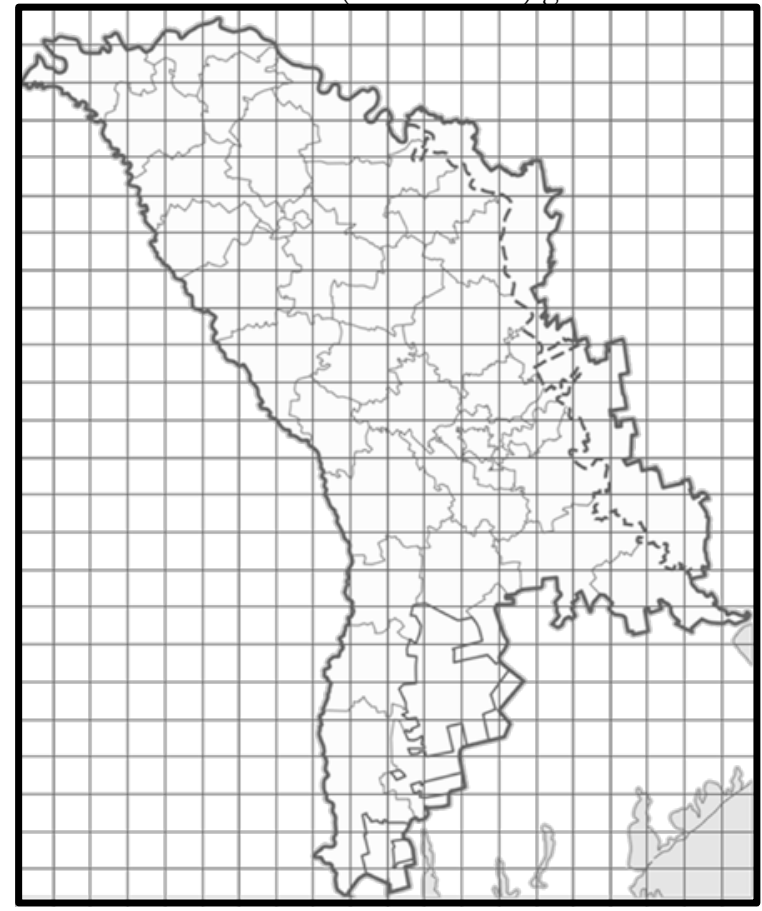

